\title{
The relationships among prospective teachers' teacher efficacy with their levels of academic motivation, academic procrastination, and anxiety about the Public Personnel Selection Examination (PPSE)
}

\author{
Asuman Seda SARACALOĞLU ${ }^{* a}$, Beste DINÇER ${ }^{* * a}$, Muhammed EKEN ${ }^{* * * a}$ Sinan BAYIK $^{* * * a}$ \\ ${ }^{\text {a } A d n a n ~ M e n d e r e s ~ U n i v e r s i t y, ~ F a c u l t y ~ o f ~ E d u c a t i o n, ~ A y d ı n / T u r k e y ~}$
}

Article Info

\begin{tabular}{|c|c|}
\hline DOI: 10.31 & 04/ijocis.2020.003 \\
\hline Article His & \\
\hline Received & 11 March 2020 \\
\hline Revised & 27 March 2020 \\
\hline Accepted & 5 June 2020 \\
\hline Online & 8 June 2020 \\
\hline Keywords: & \\
\hline $\begin{array}{l}\text { Teacher ef } \\
\text { academic } \\
\text { PPSE anxie }\end{array}$ & $\begin{array}{l}\text { cacy, } \\
\text { otivation, } \\
\text {. }\end{array}$ \\
\hline Article Typ & \\
\hline Research & \\
\hline
\end{tabular}

\begin{abstract}
The purpose of this study was to determine the relationships among the prospective teachers' teacher efficacy and their level of academic motivation, anxiety of PPSE academic procrastination levels. The research was designed as correlational survey method. The sample of the research was composed of 187 prospective teachers. According to the results of the study, there was a low and positive correlation between teacher efficacy and academic procrastination behaviors and also moderate and positive correlation with academic motivation levels of the prospective teachers. In addition, teacher candidates' academic procrastination behaviors, academic motivations and PPSE concerns explained $22 \%$ of the teacher efficacy of candidates.
\end{abstract}

\section{Öğretmen adaylarının öğretmen yetkinlikleri ile akademik güdülenme, akademik erteleme, Kamu Personel Seçme Sınavı (KPSS) kaygı düzeyleri arasındaki ilişki}

\begin{tabular}{|c|c|}
\hline \multicolumn{2}{|c|}{ Makale Bilgisi } \\
\hline \multicolumn{2}{|c|}{ DOI: $10.31704 /$ ijocis.2020.003 } \\
\hline \multicolumn{2}{|c|}{ Makale Geçmişi: } \\
\hline Geliş & 11 Mart 2020 \\
\hline Düzeltme & 27 Mart 2020 \\
\hline Kabul & 5 Haziran 2020 \\
\hline Çevrimiçi & 8 Haziran 2020 \\
\hline \multicolumn{2}{|c|}{$\begin{array}{l}\text { Anahtar Kelimeler: } \\
\text { Öğretmen yetkinliği, } \\
\text { akademik güdülenme, } \\
\text { KPSS kaygıSı }\end{array}$} \\
\hline \multicolumn{2}{|c|}{ Makale Türü: } \\
\hline
\end{tabular}

\section{Öz}

$\mathrm{Bu}$ araştırmada öğretmen adaylarının öğretmen yetkinliklerinin, akademik güdülenme düzeyleri, KPSS kaygıları ve akademik erteleme düzeyleri ile olan ilişkisi araştırılmıştır. Araştırma ilişkisel tarama modelinde desenlenmiştir. Araştırmanın örneklemini 187 öğretmen adayı oluşturmuştur. Araştırma sonucunda öğretmen adaylarının öğretmen yetkinlikleri ile akademik erteleme düzeyleri arasında pozitif yönlü düşük, akademik güdülenme düzeyleri ile de pozitif yönlü ve orta düzeyde anlamlı ilişkileri olduğu görülmüştür. Ek olarak öğretmen adaylarının akademik erteleme davranışları, akademik güdülenmeleri ve KPSS kaygılarının adayların öğretmen yetkinliklerinin \%22'sini açıkladığı saptanmıştır.

\footnotetext{
* Author: sedasaracal@gmail.com

** Author: bdincer@adu.edu.tr

*** Author: muhammed.ekeen@gmail.com

*** Author: sinanbayik@gmail.com
}

Orcid ID: https://orcid.org/0000-0001-7980-0892 Orcid ID: https://orcid.org/0000-0002-9264-3665 Orcid ID: https://orcid.org/0000-0002-9390-9218 Orcid ID: https://orcid.org/0000-0003-3353-6621 


\section{Introduction}

In the $21^{\text {st }}$ century, it is seen that the world is changing rapidly in many areas. Undoubtedly, this transformation also deeply affects education systems. Therefore, education institutions need to be able to adapt themselves to this century. The fact that learning standards are effective in contemporary societies increases the importance of effective education. Within this changing order, education and the concepts it includes also differ from those of the previous century, and an attempt is being made to adapt them to this change and transformation (Darling-Hammond, 2006).

Increasing quality in education environments depends to a large extent on effective teachers who can bring students and meaningful learning activities together, create a definite routine in their classrooms and succeed in establishing positive teacher-student relationships (Rimm-Kaufman \& Hamre, 2010). Ipek \& Demirel (2012) stated that the quality of the education given to prospective teachers is not enough to train good teachers on its own, and that in addition to the knowledge, skills and technical equipment provided, developing their skills for grappling with difficulties and their belief that they can succeed in the tasks given to them are also required. For this reason, acquisition of these skills by teachers during their preservice training is very important for modern-day education.

While Bandura (1977) was explaining the concept of efficacy, he spoke of a belief which enables individuals to display a high level of performance in line with their competences and which affects their ideas, feelings, motivation and behaviors. Moreover, Bandura separated the concept of efficacy into two, as outcome expectation and self-competence/self-efficacy. Outcome expectation represents people's expectations related to the outcomes of behaviors displayed towards a task, while selfcompetence/self-efficacy is defined as individuals' beliefs in their skills and competences for overcoming difficulties that they may encounter in order to achieve the desired result in a subject (Bandura, 1977, cited in Baloğlu \& Karadağ, 2008; Schriver \& Czerniak, 1999). Similarly, the definition of "competence" is accepted as a combination of knowledge, skills and behaviors used to increase performance or being able to perform a sufficiently qualified and assigned task (Nessipbayeva, 2012). Therefore, the concept of competence is primarily a process that will take place internally about the person himself, and then expresses the work done by the person and the resulting behaviors that will affect others.

In accordance with Bandura (1977), teacher efficacy has been brought into the literature with the studies associated with many meaningful educational outcomes of Tschannen-Moran \& Hoy (1998, $2001,2002,2007)$. In the original literature, the concept translated as teacher competence into Turkish, which was named "Ohio Teacher Efficacy" by Tschannen-Moran \& Hoy (2001) was used as teacher competence instead of teacher efficacy in the literature (Consultant, Farmer, Tosuntaş \& Karadağ, 2016; İpek \& Demirel, 2012; Saracaloğlu, Cartel, Varol \& Bahadır, 2012; Tuluk, 2015). However, in many studies (Alkan, Acarlı \& Altundağ, 2017; Çimen-Coşkun \& Sarı, 2012; Özenç \& Çelebi, 2017), the concept was used as efficacy. In this study, the concept of teacher efficacy was preferred by keeping to the name of the translated scale.

The concept of efficacy has been associated with cognitive and affective domains in connection with definitions, and the researches have been conducted to provide a more qualified educational environment. It has been determined that teachers with high efficacy levels are more successful and have greater job satisfaction, whereas those with low levels are more stressed and insecure (Nathaniel, Sandilos, Pendergast \& Mankin, 2016). When the literature is examined, it is seen that there are studies that support this situation (Malinen \& Savolainen, 2016; Perera, Granziera \& Mcllveen, 2018). Teachers with a high perception of self-efficacy are people who are open to new ideas, are willing to try new teaching methods, are less critical towards students who make mistakes, are more willing with regard to teaching, respond to students' needs, are inclined to create warm learning environments, are more persistent and resolute in the face of students' learning difficulties and when encountering any 
Asuman Seda Saracaloğlu, Beste Dinçer, Muhammed Eken, Sinan Bayık - Uluslararası Eğitim Programlar ve Öğretim Çalışmaları Dergisi, 10 (1), 2020, 53-82

problem, and conduct student-centered lessons (Henson, 2001; Tschannen-Moran \& Hoy 2001). High self-efficacy belief causes teachers to be less critical when students make mistakes, work for a longer period with students who have difficulty, and be less likely to send problem students for special education (Saracaloğlu, Certel, Varol \& Bahadır, 2012; Saracaloğlu, Yenice \& Özden, 2013). Similarly, Moalosi (2013) stated that high teacher self-efficacy shows that teachers perform better in their jobs, they do their jobs more organized, they are more patient with students who try to learn and they spend more time designing new teaching activities. When examining according to lesson variable, Saracaloğlu and Yenice (2009) stated that high levels of self-efficacy belief in science teachers play a big role in development of both the students they teach and themselves.

In other words, it is stated that high competency leads to more effort and permanence, which brings not only better performance in teaching but also more competence. Teachers with low selfefficacy perception, however, are people who have pessimistic views related to student motivation, depend on strict classroom rules, resort to punishment, conduct teacher-centered lessons, and conduct their lessons by reading from course books (Tschannen-Moran et al., 1998). This emerges as an undesired situation in education and training environments. Indeed, Bandura (2010) also emphasises that people with low self-efficacy show a tendency to amplify potential problems and threats and dwell on their shortcomings. Some teachers' beliefs that their students will succeed are high and others have low expectations, they do not take responsibility for their students who are academically unsuccessful and do not give up the authority of teachers, as a sign of low teacher selfefficacy (Schriver \& Czerniak, 1999). Therefore, it is necessary to determine teachers' levels of efficacy during their preservice training and to provide training towards this. Schunk (1991) discussed the connection between teacher efficacy and academic motivation and argued that teachers with low teacher efficacy did not demonstrate the belief and effort needed to carry out the activities required for students' development, and that, contrary to this, teachers with high teacher efficacy made great efforts for their students and prepared extra material and activities for students with learning difficulties (Ashton \& Webb, 1986), and that this also had an effect on their students' academic motivation. Accordingly, the behaviors displayed by teachers with high efficacy levels increase students' academic motivation, and as a result of this, as in the outcome expectation mentioned by Bandura (1977), they also increase teachers' levels of efficacy.

Motivation, which can be described as an important component of teacher efficacy, is defined as being energized to do something, those willing to do this and to actively participate are described as driven or motivated, and those who are unwilling are defined as motiveless or unmotivated (Ryan \& Deci, 2000). The term academic motivation, however, is used to express the motivation that students show towards academic subjects or activities. When the literature is examined, it is seen that there are many studies that examine the relationship between academic motivation and achievement (An, 2015; Bailey \& Philips, 2016; Calp \& Bacanlı, 2016). Moreover, the literature also includes studies that reveal a positive relationship between teacher efficacy and academic motivation (Kim \& Cho, 2014; Rodriguez, Blas, Valle, Piñeiro \& Cerezo, 2014; Saracaloğlu, Kumral \& Kanmaz, 2009).

Another concept mentioned in this research, defined as the students' failure to fulfill their duties and responsibilities in an academic environment, is academic procrastination. Steel (2007) reported that students' postponement, for various reasons, of the tasks they are required to carry out is defined as academic procrastination and that the negative results caused by this are steadily increasing globally. There are a number of reasons for academic procrastination. Meta-analysis studies (Kim \& Seo, 2015; Van Eerde, 2003) carried out in relation to this reveal a negative relationship of academic procrastination with self-efficacy, academic motivation and academic achievement, while they indicate a positive relationship with the concepts of fear of failure, avoidance and perfectionism. Howell and Watson (2007) stated that students whose cognitive and metacognitive learning strategies are low have high levels of academic procrastination. 
Asuman Seda Saracaloğlu, Beste Dinçer, Muhammed Eken, Sinan Bayık - Uluslararası Eğitim Programlar ve Öğretim Çalışmaları Dergisi, 10 (1), 2020, 53-82

Because, prospective teachers have to achieve before teaching in state institutions Public Personnel Selection Examination (PPSE/KPSS in Turkish) can be considered as one of the key variables in this study. This exam, which is centrally located for undergraduate third and fourth grade students, seems to have negative effects on psychology of many students and cause exam anxiety (Karataş \& Güleş, 2013; Sezgin \& Duran, 2011). Although anxiety is generally perceived as negative thoughts, possible threats or worries about our fears, it is not a bad situation to always be experienced. As one of the affective factors affecting learning, moderate anxiety can help provide motivation; Low and high anxiety levels are known to bring along some problems. For example, the number of participants in a large-scale study, prepared for the university entrance exam in Turkey trait anxiety levels of students, has been shown to be higher than the anxiety levels of patients will have surgery (Ümmet \& Otrar, 2015). In the literature, besides the studies determining anxiety levels related to PPSE (Çetin, 2013; Ümmet \& Otrar, 2015); PPSE exam anxiety and teaching profession attitude (Okçu \& Halil, 2009); studies examining different variables such as burnout and PPSE anxiety levels (Köse, Diken \& Gül, 2017; Yavuz \& Akdeniz, 2019) were found. However, there is no study examining PPSE exam anxiety, academic motivation and academic procrastination behavior, which is thought to affect teacher efficacy which is directly related to prospective professional lives.

The aim of this study is to examine the relationship of preservice teachers' teacher efficacy with their levels of academic motivation, anxiety about the PPSE and academic procrastination. Conducting studies such as these is important for determining the factors affecting teachers' efficacy during their preservice training and for carrying out the necessary relevant interventions. In line with this, answers were sought to the following questions:

1. At what levels are preservice teachers' teacher efficacy, academic motivation, academic procrastination and anxiety about the PPSE?

2. Do preservice teachers' levels of teacher efficacy, academic motivation, academic procrastination and anxiety about the PPSE vary according to

\subsection{Gender,}

2.2. Undergraduate program, or

\subsection{Class level?}

3. What kind of relationship does preservice teachers' level of teacher efficacy have with their levels of teacher efficacy, academic motivation, academic procrastination and anxiety about the PPSE?

4. What are the variables that significantly predict preservice teachers' levels of teacher efficacy?

\section{Method}

\section{Research Design}

In the research, the correlational survey model, which is one of the qualitative research designs and determines the relationships between two or more variables (Karasar, 2009), was used. The correlational survey model was used because the relationship of preservice teachers' teacher efficacy with their levels of academic procrastination, anxiety towards the PPSE exam and academic motivation are examined in this study.

\section{Study Group}

The participants in this study were determined with convenience sampling, which is one of the purposive sampling methods. Convenience sampling is related to easier inclusion in the research process of groups to be examined or easier access to these groups, and thanks to this, makes the process faster and more practicable for the researcher (Ekiz, 2015; Yıldırım \& Şimşek, 2013). The study 
Asuman Seda Saracaloğlu, Beste Dinçer, Muhammed Eken, Sinan Bayık - Uluslararası Eğitim Programlar ve Öğretim Çalışmaları Dergisi, 10 (1), 2020, 53-82

group of the research consists of 187 preservice teachers studying in the third and fourth grades of the Art Teaching, Primary School Teaching and Social Sciences Teaching programs at the Education Faculty of Adnan Menderes University, Aydın. 58\% of the participants of the research were female, and $42 \%$ were male. Moreover, 84 (45\%) of the participants were in the third grade, and $103(55 \%)$ were in the fourth grade. According to the programs that prospective teachers study, it is seen that 83 of them are in Social Studies Education, 54 of them are in Classroom Education, and 50 of them are in Art Education.

\section{Data Collection Instruments}

In the research, the data were collected with four data collection tools in addition to the personal information form developed to collect the participants' information such as age, gender, department and grade levels.

Personal Information Form: This was created by the researchers to obtain information such as participants' gender, age, class level, and departments.

Ohio State Teacher Efficacy Scale: This scale was developed by Tschannen-Moran \& Woolfolk-Hoy (2001) to determine teachers' levels of efficacy, and was adapted for Turkish language and culture by Baloğlu \& Karadağ (2008). While the adaptation study was being made, the following procedures were carried out: examination of validity of English-Turkish translation, validity of language and meaning of Turkish form, linguistic equivalence between English and Turkish forms, content validity, item total and item-rest correlations, item discrimination characteristics, structural validity, internal consistency, Guttman split-half and Spearman-Brown reliability methods, correlations between subscales and testretest reliability. As a result of these procedures, it was seen that the scale was suitable for Turkish language and culture. The scale is a 5-point Likert-type scale consisting of 24 items and 5 subdimensions. A Cronbach's alpha internal consistency coefficient of 0.80 was found for the scale. In the present study, the internal consistency coefficient of the scale was determined to be 0.93 .

Academic Motivation Scale: This scale was developed by Bozanoğlu (2004) to determine secondary school students' levels of academic motivation. For determining the reliability of the scale, a testretest, in which 101 students took part, was used, and correlation between the two applications was revealed to be .87 . Moreover, the internal consistency coefficients (Cronbach's alpha) calculated as proof of reliability were found to range from .77 to .85 at different times and from .77 to .86 in different groups. The scale consists of three sub-dimensions and 20 questions of the 5-point Likert type. In the current study, the internal consistency coefficient of the scale was found to be 0.87 .

Academic Procrastination Scale: Developed by Çakıcı (2003) to reveal the academic procrastination behaviours of students, this scale consists of 19 items of the 5-point Likert type and two subdimensions. Since Çakıcı stated that the scale could also be used as a single dimension, it was used as a one-dimensional scale in this study. A Cronbach's alpha internal consistency coefficient of 0.92 was found for the scale in Çakıcı's study. In this study, however, the internal consistency coefficient was calculated as 0.83 .

Scale of Anxiety about the Public Personnel Selection Examination: This scale was created by Karaçanta (2009) with the aim of assessing exam anxiety levels of preservice teachers who are to enter PPSE. The scale is made up of 4 sub-dimensions, namely general anxiety, concerns about how you see yourself and how others see you, concerns about the future and concerns about exam preparation, and a total of 19 items of the 5-point Likert type. The results of the exploratory factor analysis that was made reveal that the scale is a valid data collection tool. A Cronbach's alpha internal consistency coefficient of 0.88 was found for the scale. In this study, however, the internal consistency coefficient was determined to be 0.81 . 


\section{Data Collection Process}

The research data were gathered by the researchers during the spring term of the 2016-2017 academic year. The scales used in the research were distributed in written form to volunteer students and the forms given were filled in about 10-15 minutes. The gathered data were coded for analysis on the SPSS program by the researchers.

\section{Data Analysis}

The data collected from the participants were coded electronically by the researchers and the data were analyzed through a package program. The research data were answered by 203 participants. However, when the data were checked, it was seen that 10 participants left the scales halfway or encoded sloppily. In addition, since the answers of 6 participants were at extreme values, these 16 participants were removed from the data set. In the analysis, it was checked whether the data was normally distributed to determine whether parametric tests would be applied. Normality assumptions were checked by looking at the ratio of kurtosis and skewness values to error values, and the values were found to range between -1.00 and +1.00 . Mahalanobis distance coefficient and scatter diagram were examined to examine the multiple normality of the data. The Mahalanobis distance value coefficient of the variables was determined to be a maximum of 13.551 and it was found that multiple normality was provided. In addition, when looking at the VIF values of the independent variables to check whether there are multiple connections, it was seen that the values were between 1.017 and 1.052 and the tolerance values $(\mathrm{Cl})$ were not higher than 15 . Finally, Durbin Watson coefficient was examined to examine autocorrelation between variables.

The Durbin Watson coefficient was found to be 2.00 and this value was found to be between 1.52.5 , which is shown as the threshold value by Field (2005). After controlling the assumptions required for the analysis, the relationship between pre-service teachers' teacher competence, academic motivation, academic procrastination and PPSE anxiety levels and gender and grade level variables were tested by independent groups t-test, and the relation of these variables with the program registered was one-way variance analysis. In addition, in order to determine the relationship between the dependent variables, Pearson correlation analysis and multiple regression analyzes related to predicting teacher efficacies of pre-service teachers together with independent variables were made and presented in the findings.

\section{Findings}

In this section of the study, the findings obtained by analyzing collected data in order to analyze the sub-problems of the research were presented.

\section{Prospective Teachers' Levels of Teacher Efficacy, Academic Motivation, Academic Procrastination and PPSE Anxiety}

In order to answer the first research question of the study, the average scores of teacher efficacy, academic education, academic procrastination and PPSE anxiety levels of prospective teachers are presented in Tables 1, 2, 3, and 4.

Table 1.

Prospective Teachers' Levels of Teacher Efficacy, Academic Motivation, Academic Procrastination, and PPSE Anxiety

\begin{tabular}{lccc}
\hline Variables & $\mathbf{N}$ & $\overline{\mathbf{X}}$ & Sd \\
\hline Academic Procrastination & 187 & 2.981 & .523 \\
PPSE Anxiety & 187 & 2.790 & .612 \\
Academic Motivation & 187 & 3.151 & .574 \\
Teacher Efficacy & 187 & 3.730 & .621 \\
\hline
\end{tabular}


Asuman Seda Saracaloğlu, Beste Dinçer, Muhammed Eken, Sinan Bayık - Uluslararası Eğitim Programlar ve Öğretim Çalışmaları Dergisi, 10 (1), 2020, 53-82

When Table 1 is examined, it is seen that the prospective teachers' levels of academic motivation $(\bar{X}=3.15)$ and teacher efficacy $(\bar{X}=3.73)$ were high, while their levels of PPSE anxiety $(\bar{X}=2.79)$ and academic procrastination ( $\bar{X}=2.98)$ were close to moderate.

Table 2.

Prospective Teachers' Levels of Teacher Efficacy

\begin{tabular}{lccc}
\hline Sub-dimensions & $\boldsymbol{N}$ & $\overline{\boldsymbol{X}}$ & $\boldsymbol{S d}$ \\
\hline Behavior Management & 187 & 3.71 & .668 \\
Motivation & 187 & 3.80 & .701 \\
Teaching Skills & 187 & 3.70 & .717 \\
Measurement and Evaluation & 187 & 3.67 & .782 \\
Total & 187 & 3.72 & .621 \\
\hline
\end{tabular}

When the sub dimensions of the prospective teachers' teacher efficacy in Table 2 are examined, it is seen that the motivation sub dimension has the highest mean value $(\bar{X}=3.80)$, while the measurement and evaluation sub-dimension has the lowest mean value ( $\bar{X}=3.67)$.

Table 3.

Prospective Teachers' PPSE Anxiety Levels

\begin{tabular}{lccc}
\hline Sub-dimensions & $\boldsymbol{N}$ & $\overline{\boldsymbol{X}}$ & $\boldsymbol{S d}$ \\
\hline General Anxiety & 187 & 2.55 & .742 \\
Others' Anxiety & 187 & 2.72 & .806 \\
Concerns about the Future & 187 & 3.36 & .915 \\
Concerns about Exam Preparation & 187 & 3.01 & .894 \\
Total & 187 & 2.79 & .612 \\
\hline
\end{tabular}

Table 3 shows the scores obtained by the prospective teachers in the sub dimensions of the PPSE anxiety scale. It can be seen that the highest levels of anxiety were in the sub dimension related to concerns about the future $(\bar{X}=3.36)$, while the lowest were in the general anxiety sub-dimension $(\bar{X}=2.55)$.

Table 4.

Prospective Teachers' Levels Of Academic Motivation

\begin{tabular}{lccc}
\hline Sub-dimensions & $\boldsymbol{N}$ & $\overline{\boldsymbol{X}}$ & $\boldsymbol{S d}$ \\
\hline Using knowledge & 187 & 2.55 & .742 \\
Challenging oneself & 187 & 2.72 & .806 \\
Discovery & 187 & 3.36 & .915 \\
Total & 187 & 2.79 & .612 \\
\hline
\end{tabular}

The scores obtained by the preservice teachers in the sub-dimensions of the academic motivation scale can be seen in Table 4 . The highest mean score was obtained in the discovery sub-dimension $(\bar{X}=3.36)$ related to discovering new things, while the lowest mean score was obtained in the subdimension related to using knowledge $(\bar{X}=2.55)$.

\section{Findings Related to the Gender Variable}

To determine whether or not the independent variable of gender of the participants had an effect on their academic procrastination, academic motivation, PPSE anxiety and teacher efficacy, analysis was performed with t-test for independent variables.

Table 5.

Independent Groups T-test Results According to Gender of Prospective Teachers

\begin{tabular}{llccccc}
\hline Variables & Gender & $\boldsymbol{N}$ & $\overline{\boldsymbol{X}}$ & $\boldsymbol{S d}$ & $\boldsymbol{t}$ & $\boldsymbol{p}$ \\
\hline \multirow{2}{*}{ Academic Procrastination } & Female & 109 & 2.93 & 0.592 & & \multirow{2}{*}{0.132}
\end{tabular}


Asuman Seda Saracaloğlu, Beste Dinçer, Muhammed Eken, Sinan Bayık - Uluslararası Eğitim Programlar ve Öğretim Çalışmaları Dergisi, 10 (1), 2020, 53-82

Table 5 (Cont.)

\begin{tabular}{llccccc}
\hline \multirow{2}{*}{ Academic Motivation } & Female & 109 & 3.68 & 0.535 & -1.434 & 0.153 \\
& Male & 78 & 3.80 & 0.576 & & \\
PPSE Anxiety & Female & 109 & 2.76 & 0.589 & -0.825 & 0.410 \\
& Male & 78 & 2.83 & 0.643 & & \\
Teacher Efficacy & Female & 109 & 3.76 & 0.575 & \multirow{2}{*}{0.705} & 0.482 \\
\hline & Male & 78 & 3.69 & 0.681 & &
\end{tabular}

Examination of Table 5 reveals the independent groups t-test results for scores obtained by the prospective teachers from the measurement instruments according to the gender variable. Accordingly, it is seen that there was no significant difference in the preservice teachers' scores for academic procrastination, academic motivation, PPSE anxiety or teacher efficacy according to the gender variable.

\section{Findings Related to the Class Level Variable}

To determine whether or not the independent variable of class level of the participants had an effect on their academic procrastination, academic motivation, PPSE anxiety and teacher efficacy, analysis was performed with t-test for independent variables.

Table 6.

Independent Groups T-test Results According to Class Levels of Prospective Teachers

\begin{tabular}{llccccc}
\hline Variables & Grade Level & $\boldsymbol{N}$ & $\overline{\boldsymbol{X}}$ & $\boldsymbol{S d}$ & $\boldsymbol{t}$ & $\boldsymbol{p}$ \\
\hline \multirow{2}{*}{ Academic Procrastination } & $3^{\text {rd }}$ grade & 84 & 2.98 & .576 & \multirow{2}{*}{0.001} & 0.999 \\
& $4^{\text {th }}$ grade & 103 & 2.98 & .478 & & \\
Academic Motivation & $3^{\text {rd }}$ grade & 84 & 3.64 & .553 & -2.203 & 0.029 \\
& $4^{\text {th }}$ grade & 103 & 3.81 & .545 & & \\
PPSE Anxiety & $3^{\text {rd }}$ grade & 84 & 2.73 & .557 & -1.231 & 0.220 \\
& $4^{\text {th }}$ grade & 103 & 2.84 & .652 & & \\
Teacher Efficacy & $3^{\text {rd }}$ grade & 84 & 3.74 & .620 & 0.268 & 0.789 \\
\hline${ }^{*} p<.05$ & $4^{\text {th }}$ grade & 103 & 3.72 & .625 & &
\end{tabular}

Table 6 shows the $t$-test results for scores obtained by the prospective teachers from the measurement instruments according to the class level variable. Accordingly, while no statistically significant difference was observed in the prospective teachers' levels of academic procrastination, PPSE anxiety or teacher efficacy, a significant difference was found in levels of academic motivation in favor of $4^{\text {th }}$ grade students $(t=-2.203, p=0.029)$. Therefore, to see in which sub-dimensions of the academic motivation scale there was a difference, $t$-test was carried out, and the results are shown in Table 7 below.

Table 7.

T-test Results for Academic Motivation According to Prospective Teachers' Class Levels

\begin{tabular}{llccccc}
\hline Sub-dimensions & Grade Level & $\mathbf{N}$ & $\mathbf{X}$ & $\mathbf{S d}$ & $\mathbf{t}$ & $\mathbf{p}$ \\
\hline \multirow{2}{*}{ Using knowledge } & $3^{\text {rd }}$ grade & 84 & 3.92 & 0.60 & -1.291 & 0.198 \\
& $4^{\text {th }}$ grade & 103 & 4.04 & 0.66 & & \\
Challenging oneself & $3^{\text {rd }}$ grade & 84 & 3.57 & 0.70 & -2.216 & 0.036 \\
& $4^{\text {th }}$ grade & 103 & 3.78 & 0.66 & & \\
Discovery & $3^{\text {rd }}$ grade & 84 & 3.46 & 0.64 & -2.146 & 0.033 \\
& $4^{\text {th }}$ grade & 103 & 3.65 & 0.59 & & \\
Total & $3^{\text {rd }}$ grade & 84 & 3.64 & 0.55 & -2.203 & 0.029 \\
${ }^{*} p<.05$ & $4^{\text {th }}$ grade & 103 & 3.81 & 0.54 & & \\
\end{tabular}


Asuman Seda Saracaloğlu, Beste Dinçer, Muhammed Eken, Sinan Bayık - Uluslararası Eğitim Programlar ve Öğretim Çalışmaları Dergisi, 10 (1), 2020, 53-82

It can be seen in Table 7 that while no statistically significant difference was found in the using knowledge sub-dimension of the academic motivation scale according to the preservice teachers' class levels, statistically significant differences were observed in the sub-dimensions of challenging oneself $(t=-2.216, p=0.036)$ and discovery $(t=-2.146, p=0.033)$.

\section{Findings Related to the Department Variable}

To determine whether or not the independent variable of department attended by the participants had an effect on their academic procrastination, academic motivation, PPSE anxiety and teacher efficacy, analysis was performed with one-way analysis of variance.

Table 8.

One-way Analysis of Variance Values Related to Department Attended by Prospective Teachers

\begin{tabular}{|c|c|c|c|c|c|c|}
\hline Variables & Source of Variance & Sum of Squares & Sd & Means Square & $\mathbf{F}$ & $\mathbf{p}$ \\
\hline \multirow{3}{*}{$\begin{array}{l}\text { Academic } \\
\text { Procrastination }\end{array}$} & Intergroup & .111 & 2 & .056 & & \\
\hline & Intragroup & 50.789 & 184 & .276 & 0.202 & 0.818 \\
\hline & Total & 50.900 & 186 & & & \\
\hline \multirow{3}{*}{$\begin{array}{l}\text { Academic } \\
\text { Motivation }\end{array}$} & Intergroup & .985 & 2 & .493 & & \\
\hline & Intragroup & 56.137 & 184 & .305 & 1.614 & 0.202 \\
\hline & Total & 57.122 & 186 & & & \\
\hline \multirow{3}{*}{ PPSE Anxiety } & Intergroup & .846 & 2 & .423 & & \\
\hline & Intragroup & 68.824 & 184 & .374 & 1.131 & 0.325 \\
\hline & Total & 69.670 & 186 & & & \\
\hline \multirow{3}{*}{ Teacher Efficacy } & Intergroup & .359 & 2 & .179 & & \\
\hline & Intragroup & 71.451 & 184 & .388 & 0.462 & 0.631 \\
\hline & Total & 71.809 & 186 & & & \\
\hline
\end{tabular}

In Table 8, one-way analysis of variance results obtained by the prospective teachers from the measurement instruments according to the department they attended are shown. When the table is examined, it is seen that according to the variable of department attended, there was no statistically significant difference in the prospective teachers' levels of academic procrastination $(F=0.202, p=$ $0.818)$, academic motivation ( $\mathrm{F}=1.614, p=0.202)$, PPSE anxiety $(\mathrm{F}=1.131, p=0.325)$ or teacher efficacy $(\mathrm{F}=0.462, p=0.631)$ according to the type of program they were registered on.

\section{Findings Related to the Relationships between Participants' Levels of Academic Motivation, Academic Procrastination, Teacher Efficacy and PPSE Anxiety}

The results of the Pearson correlation analysis that was performed to determine the relationships among the dependent variables of the research are presented below in Table 9.

Table 9.

Relationships between Teacher Efficacy, Academic Motivation, Academic Procrastination and PPSE Anxiety

\begin{tabular}{lcccc}
\hline Variables & $\begin{array}{c}\text { Academic } \\
\text { Procrastination }\end{array}$ & $\begin{array}{c}\text { Academic } \\
\text { Motivation }\end{array}$ & PPSE Anxiety & $\begin{array}{c}\text { Teacher } \\
\text { Efficacy }\end{array}$ \\
\hline Academic Procrastination & 1 & & & \\
Academic Motivation & $-0.20^{*}$ & 1 & 1 & \\
PPSE Anxiety & 0.09 & 0.08 & -0.02 & 1 \\
Teacher Efficacy & $-0.19^{*}$ & $0.46^{*}$ & &
\end{tabular}

Table 9 shows the relationships between the prospective teachers' levels of academic procrastination, academic motivation, PPSE anxiety and teacher efficacy. Accordingly, a weak negative relationship of the preservice teachers' academic motivation $(R=-0.20, p=0.007)$ and teacher efficacy $(\mathrm{R}=-0.19, p=0.008)$ with their levels of academic procrastination can be seen. This shows that as the preservice teachers' levels of academic procrastination increased, their academic motivation and teacher efficacy decreased, and that the contrary was also true. Moreover, a moderate positive 
Asuman Seda Saracaloğlu, Beste Dinçer, Muhammed Eken, Sinan Bayık - Uluslararası Eğitim Programlar ve Öğretim Çalışmaları Dergisi, 10 (1), 2020, 53-82

relationship ( $\mathrm{R}=0.46, p=0$ ) can also be observed between the prospective teachers' levels of academic motivation and teacher efficacy.

\section{Variables Predicting the Prospective Teachers' Levels of Teacher Efficacy}

The results of multiple regression analysis on variables predicting teacher competence levels of prospective teachers are presented in Table 10.

Table 10.

Results of Multiple Regression Analysis for Prediction of Prospective Teachers' Levels of Teacher Efficacy by the Independent Variables Together

\begin{tabular}{|c|c|c|c|c|c|c|c|c|c|}
\hline Variables & B & $\begin{array}{l}\text { Std. } \\
\text { Error }\end{array}$ & B & $\boldsymbol{t}$ & $p$ & $\begin{array}{c}\text { Toleranc } \\
\text { e }\end{array}$ & VIF & $\mathbf{C l}$ & $95 \%$ GA \\
\hline (Fixed) & 2.341 & 0.421 & & 5.558 & 0.000 & & & 1 & $1.510 / 3.172$ \\
\hline $\begin{array}{l}\text { Academic } \\
\text { Procrastinatio }\end{array}$ & -0.118 & 0.079 & -0.100 & -1.495 & 0.137 & 0.950 & 1.052 & 10.493 & $-0.274 / 0.038$ \\
\hline $\begin{array}{l}\text { Academic } \\
\text { Motivation }\end{array}$ & 0.502 & 0.075 & 0.447 & 6.720 & 0.0 & 0.952 & 1.050 & 11.369 & $0.354 / 0.649$ \\
\hline PPSE Anxiety & -0.047 & 0.067 & -0.047 & -0.713 & 0.48 & 0.983 & 1.017 & 24.668 & $-0.179 / 0.084$ \\
\hline \multicolumn{6}{|c|}{ Efficacy $=2.341-0.118 \times A E+0.502 \times A G-0.047 \times K K$} & $\mathrm{R}^{2}=0.22$ & \multicolumn{3}{|c|}{$F_{(3.183)}=17.966$} \\
\hline
\end{tabular}

The results of the multiple regression analysis show that the created model is not valid as a whole $(F(3,183)=17.966 ; p<0.001)$ and that the independent variables accounted for $22 \%(R 2=0.22)$ of the total explained variance for teacher efficacy. When the parameters of the multiple regression model are examined, the standardized regression coefficients $(\beta)$ show that the order of importance of the predictive variables on academic self-efficacy was academic motivation $(\beta=0.447 ; t=6.720 ; p<0.01)$, PPSE anxiety $(\beta=-0.047 ; t=-0.713 ; p<0.05)$, and academic procrastination $(\beta=-0.100 ; t=-1.495 ; p>0.5)$. Taking all the variables into consideration, it is revealed that academic motivation and PPSE anxiety were each significant predictors of teacher efficacy, whereas academic procrastination was not a significant predictor. Moreover, in the multiple regression analysis, it was determined that all the $B$ values for the independent variables remained within the $95 \%$ confidence interval.

\section{Discussion, Conclusion and Implications}

As a result of the study that was carried out, it was determined that while the prospective teachers' mean scores for levels of academic motivation and teacher efficacy were high, their mean scores for academic procrastination and PPSE anxiety were at a more moderate level. Furthermore, when the sub-dimensions of the preservice teachers' efficacies were examined, it was revealed that the highest score was in the motivation sub-dimension, while the lowest score was in the measurement and evaluation sub-dimension. The fact that pre-service teachers have a high level of academic motivation, motivation and efficacy in the current study is a desirable finding because it indicates clues about the development of affective characteristics related to teaching in general.

According to a similar studies conducted by (İpek \& Demirel, 2012; Özaydınlık, 2018) it was also seen that preservice teachers' perceptions of teacher efficacy were at high levels. Again, the results of Ipek and Demirel's (2012) study support the finding that perception of self-efficacy scored high. In the study made by Vural and Gündüz (2019), it was also found that prospective teachers displayed academic procrastination behaviors at a "moderate" level. In this context, the related studies support each other.

In terms of gender variable, there was no significant difference between pre-service teachers according to academic procrastination, academic motivation, PPSE anxiety and teacher efficacy scale scores. In other words, female and male prospective teachers have similar scores in this study and gender is not a determining variable. Gündoğdu, Çimen and Turan (2008) determined that gender did 
Asuman Seda Saracaloğlu, Beste Dinçer, Muhammed Eken, Sinan Bayık - Uluslararası Eğitim Programlar ve Öğretim Çalışmaları Dergisi, 10 (1), 2020, 53-82

not make a significant difference in the researches that prospective teachers examined PPSE anxieties. On the other hand, different results draw attention according to the results of the study in the related literature. For example in some studies, male prospective teachers (Balkıs \& Duru, 2009; Demir \& Ferrari, 2009; Dinçer \& Gerceker, 2018; Gökdere \& Çakır, 2015; Uzun Özer, Demir \& Ferrari ,2009; Vural \& Gündüz, 2019); In some studies, it is remarkable that females have higher academic procrastination level (Mişe \& Hançer, 2019; Özer \& Ferrari, 2011). However, similar to the current study, Cikrikci \& Erzen (2016) did not find a significant difference in the meta-analysis study, where they examined whether gender was a determining factor in academic procrastination.

With regard to academic motivation level, it was also stated in a study by Şahin and Çakar (2011) that while no significant difference was found in preservice teachers' levels of academic motivation according to gender, there was a statistically significant difference between the prospective teachers according to the departments they attended. Similarly, it was stated in Demir and Arı's (2013) study that while a significant difference was not found in preservice teachers' levels of academic motivation according to gender, a statistically significant difference was determined between the prospective teachers in terms of the departments they attended. On the other hand, in Gerçeker and Şeker's study (2013) conducted with prospective teachers in a music teaching department, in the subdimensions of academic motivation, a significant difference was found in favour of the using knowledge subdimension, in parallel with the present study. Aktaş (2017), in his study with the students of the Faculty of Theology, revealed that gender did not make a significant difference in the academic motivation levels of students. Studies on this aspect correspond with the results of the relevant study.

In a study on the subject of PPSE anxiety level made by Karaçanta and Koç (2015), it was concluded that with regard to PPSE anxiety, the gender variable was a positive predictor of PPSE anxiety, and that anxiety level in males was correlationally lower than anxiety level in females. Similarly, in a study on the subject of anxiety carried out with a different scale by Köse, Diken and Gül (2017) with preservice biology teachers, it was concluded that there was a difference in anxiety levels according to gender. With regard to academic procrastination behavior, in Bulut's (2014) master's thesis study carried out with prospective teachers in social sciences, statistically significant differences were found in the preservice teachers' academic procrastination behaviour according to gender and class level. Similarly, in the study conducted by Gerçeker and Şeker (2013) with prospective teachers in the art teaching and music teaching departments of fine arts, significant differences were found with regard to gender, department and class level. Wu and Fan (2017) stated that academic procrastination behavior is related to academic motivation, and procrastination behavior increases as motivation decreases.

However, when the class level variable is examined, there is no significant difference between academic procrastination, PPSE anxiety and teacher efficacy levels, there is a significant difference in the levels of academic motivation in terms of self-transcendence and discovery. This means that, as the grade level progresses, prospective teachers feel closer to the teaching profession and thus they are more motivated academically. Terzi, Ünal and Gürbüz (2012) found that academic motivation levels of 4 th grade students are higher than that of 2 nd grade students. Similarly, Terzi, Uyangör and Dülker (2017) found a significant difference in favor of students studying in the last year in the academic motivation levels of graduate prospective teachers who received training in their studies. On the other hand, there is no significant difference in some sub-dimensions (irresponsibility, negative perception of teachers, and academic perfectionism) in the study of Bulut and Ocak (2017) in terms of academic procrastination levels of pre-service teachers; however, it was revealed that there was a significant difference between the third and fourth grades and the first grades in favor of the third and fourth grades in one dimension (perceived quality of the academic task). In some studies, contrary to the findings obtained in this research, it was observed that the motivation of prospective teachers decreased as the grade levels increased compared to previous years (Eymur \& Geban, 2011; Gürşimşek, 2002; Uyulgan \& Akkuzu, 2014). 
Asuman Seda Saracaloğlu, Beste Dinçer, Muhammed Eken, Sinan Bayık - Uluslararası Eğitim Programlar ve Öğretim Çalışmaları Dergisi, 10 (1), 2020, 53-82

It has been determined that there is no significant difference on academic procrastination, academic motivation, PPSE anxiety and teaching efficacy within the framework of the department variable in which pre-service teachers are registered. Similar to academic motivation, Terzi, Uyangör \& Dülker (2017); Vural \& Gündüz (2019) regarding academic procrastination; The study results of Yılmaz and Yaşar (2016), Altun Altun, Avcl, Özüpekçe and Gümüş (2017) regarding PPSE anxiety are consistent with the study at hand. In addition, it was observed that prospective teachers ' efficacy levels were examined within the framework of various variables, and similar results were achieved in similar studies. In Tuluk's (2014) study, significant differences in teacher efficacy were found according to different departments. Similarly, in Demirtaş, Cömert and Özer's (2011) study, using a different scale, findings related to determination of self-efficacy indicated significant differences in some subdimensions of the scale according to gender and department.

A weak negative correlation of the preservice teachers' levels of teacher efficacy with their levels of academic motivation and academic procrastination were seen in the study. Accordingly, when the prospective teachers' levels of academic procrastination increased, their levels of academic motivation and teacher efficacy decreased. Moreover, a moderate positive relationship was observed between the prospective teachers' levels of academic motivation and teacher efficacy. The level of teacher efficacy increased as the level of academic motivation increased. Similarly, Saracaloğlu and Dinçer (2009) revealed a moderate relationship between prospective teachers' level of efficacy and academic motivation. Saracaloğlu, Kumral and Kanmaz (2009) revealed that there was a positive and significant relationship between the prospective teachers' perceptions of professional competence and their academic motivation. Alemdağ, Öncü and Yılmaz, (2014) stated the positive effect of academic motivation on academic self-efficacy in a similar study conducted with prospective physical education teachers.

When the extent to which the preservice teachers' levels of teacher efficacy were predicted by the independent variables of academic motivation, PPSE anxiety and academic procrastination was examined, it was seen that they accounted for $22 \%$ of the total variance. Levels of academic motivation and PPSE anxiety, respectively, can be stated as significant predictors of the preservice teachers' levels of academic efficacy. On the other hand, the level of academic procrastination was not determined to be a significant predictor of their levels of teacher efficacy. From this result, it can be interpreted that the pre-service teachers who have high academic motivation set their goals more clearly and they work more because they have anxiety about being appointed within the framework of these goals. Therefore, motivating prospective teachers during their education and ensuring their motivation for teaching profession; it seems necessary to develop not only academically but also affectively.

Based on the results of the research, the following recommendations can be made for researchers and practitioners:

With this study, it was revealed that academic motivation and PPSE anxieties are significant predictors of teacher efficacy. Experimental and qualitative studies can be conducted on the concept of academic motivation as a predictor of teacher efficacy and how the anxiety created by PPSE exam on prospective teachers affects their professional competencies. In order to ensure that they are trained as competent and influential teachers in their profession, the education institutions, which are the basic institutions that provide teacher education, can also organize the content of the program that supports the academic motivation of prospective teachers and includes the cognitive domain as well as affective domain acquisitions. However, as the grade level progresses, longitudinal studies can be conducted on whether or not there is a positive increase in the academic motivation levels of prospective teachers and also the positive progress of the process can be supported by examining the results. 
Asuman Seda Saracaloğlu, Beste Dinçer, Muhammed Eken, Sinan Bayık - Uluslararası Eğitim Programlar ve Öğretim Çalışmaları Dergisi, 10 (1), 2020, 53-82

\section{Acknowledgement}

This study was presented in the $5^{\text {th }}$ International Congress on Curriculum and Instruction held in Muğla,Turkey between 26-28 October 2017 as oral presentation. 


\section{TÜRKÇE SÜRÜM}

\section{Giriş}

21. yüzyılda dünyanın birçok alanda hızlı bir dönüşüm sürecine girdiği görülmektedir. Kuşkusuz bu dönüşüm, eğitim sistemlerini derinden etkilemektedir. Öğrenme standartlarının çağdaş toplumlarda daha önce olmadığı kadar yüksek olması etkili öğretimin önemini arttırmaktadır. Bu sebeple değişen bu düzen içerisinde eğitim ve içerisindeki kavramlar da 20. yüzyıla göre farklılık göstermekte, eğitim kurumları da kendilerini bu yüzyıla adapte edebilmek için değişime ve dönüşüme ayak uydurmaya çalışmaktadır (Darling-Hammond, 2006).

Eğitim ortamlarındaki niteliğin artması, büyük ölçüde öğrencileri anlamlı öğrenme etkinlikleri ile buluşturan, sınıflarında belirli bir rutin oluşturan ve pozitif bir öğretmen-öğrenci ilişkisi kurmayı başaran etkili öğretmenlere bağlıdır (Rimm-Kaufman \& Hamre, 2010). Ipek ve Demirel (2012) öğretmen adaylarına verilen eğitimin niteliğinin tek başına iyi bir öğretmen yetiştirmek için yeterli olmadığını, öğrenciyi bilgi ve beceriyle donatmanın yanı sıra zorluklarla mücadele etme ve kendilerine verilen ödev ve sorumlukları başaracaklarına dair inanç geliştirmeleri de gerektiğini belirtmişlerdir. Bu nedenle öğretmenlerin hizmet öncesi eğitimlerinde bu becerileri kazanmaları büyük bir önem arz etmektedir.

Kuramsal temelleri sosyal öğrenme kuramına dayanan yetkinlik kavramını Bandura (1977) bireylerin yetenekleri doğrultusunda üst düzey performans sergilemelerini sağlayan, düşüncelerini, hislerini, motivasyonlarını ve davranışlarını etkileyen bir inanç olarak tanımlamış ve yetkinlik kavramını sonuç beklentisi ve öz-yetkinlik olarak ikiye ayırmıştır. Sonuç beklentisi, kişilerin bir göreve yönelik olarak sergiledikleri davranışların sonuçlarına yönelik olarak sergiledikleri beklentileri temsil ederken, özyetkinlik ise bireylerin bir konuda istedikleri sonucu elde etmek için karşılaşabileceği zorlukların üstesinden gelebilmek için kendi beceri ve yeteneklerine olan inançları olarak tanımlanmıştır (Bandura, 1977, akt. Baloğlu \& Karadağ; Schriver \& Czerniak, 1999). Benzer şekilde "yetkinlik" tanımı performansı arttırmak için kullanılan bilgi, beceri ve davranışların bir kombinasyonu olarak ya da yeteri kadar nitelikli ve verilen bir görevi yerine getirebilecek durumda olmak şeklinde de kabul görmektedir (Nessipbayeva, 2012). Dolayısıyla yetkinlik kavramı öncelikle içsel anlamda kişinin kendisiyle ilgili gerçekleşecek bir süreç olup daha sonra kişinin yaptığı işi ve diğerlerini etkileyecek sonuç davranışlarını ifade etmektedir.

Bandura (1977) ile uyumlu olarak öğretmen yetkinliği, Tschannen-Moran ve Hoy'un (1998, 2001, $2002,2007)$ birçok anlamlı eğitim çıktısı ile ilişkilendirilen çalışmalarıyla alanyazına kazandırıımıştır. Orijinal dilinde Tschannen-Moran ve Hoy (2001) tarafından "Ohio Teacher Efficacy" olarak adlandırılan Türkçe'ye ise Baloğlu ve Karadağ (2008) tarafından öğretmen yetkinliği olarak çevrilen kavramın alan yazında bazı çalışmalarda öğretmen yetkinliği yerine öğretmen yeterliliği olarak kullanıldığı görülmektedir (Danışman, Çiftçi, Tosuntaş \& Karadağ, 2016; İpek \& Demirel, 2012; Saracaloğlu, Cartel, Varol \& Bahadır, 2012; Tuluk, 2015). Ancak çoğu çalışmada da (Alkan, Acarlı \& Altundağ, 2017; ÇimenCoşkun \& Sarı, 2012; Özenç \& Çelebi, 2017) söz konusu kavram yetkinlik olarak ele alınmıştır. Bu çalışmada da çevrilen ölçeğin adına sadık kalınarak öğretmen yetkinliği kavramı tercih edilmiştir.

Yetkinlik kavramı tanımlarla bağlantılı olarak bilişsel ve duyuşşsal alanlar ile ilişkilendirilmiş ve daha nitelikli bir eğitim ortamı sağlanması amacıyla araştırmalar yapıımıştır. Yüksek yetkinlik düzeyine sahip olan öğretmenlerin daha başarılı ve iş doyumlarının yüksek olduğu, düşük olanların ise daha stresli ve güvensiz bir durum içerisinde oldukları belirlenmiştir (Nathaniel, Sandilos, Pendergast \& Mankin, 2016). Alanyazın incelendiğinde bu durumu destekleyen araştırmaların da olduğu görülmektedir (Malinen \& Savolainen, 2016; Perera, Granziera \& Mcllveen, 2018). Yüksek yetkinliğe sahip öğretmenlerin öğrencilerin hatalarına yönelik daha az eleştirel olduğu ve öğrenmede güçlük çeken öğrenciler ile daha uzun süre sabırla çalıştığı belirtilmiştir (Saracaloğlu, Certel, Varol \& Bahadır, 2012; Saracaloğlu, Yenice \& Özden, 2013). Benzer şekilde Moalosi (2013) yüksek öğretmen öz yetkinliğine 
sahip olan öğretmenlerin, işlerini organize ederek daha iyi performans sergilediklerini, öğrenmeye çabalayan öğrencilere karşı daha sabırlı olduklarını ve yeni öğretim etkinliklerini tasarlamaya daha çok vakit ayırdıklarını ifade etmiştir. Ders bazında incelendiğinde de Saracaloğlu ve Yenice (2009) Fen eğitiminde yüksek yetkinliğe sahip öğretmenlerin, kendilerini geliştirmenin yanı sıra öğrencilerinin de gelişimlerinde büyük rol oynadığını belirtmişlerdir.

Başka bir anlatımla yüksek yetkinliğin, daha fazla çaba ve kalıcılığa yol açtığı, bunun da öğretimde daha iyi performans sağlamakla kalmayıp daha fazla yetkinliği beraberinde getirdiği ifade edilmektedir. Bu durumun tersi olarak da düşük yetkinliğin ise daha az çaba ve kolayca vazgeçmeye yol açıp beraberinde daha düşük yetkinliğe sahip olumsuz sonuçlar doğurduğu belirtilmektedir (TschannenMoran \& Hoy, 1998). Bu durum, eğitim öğretim ortamlarında istenmeyen bir durum olarak karşımıza çıkmaktadır. Nitekim Bandura (2010) öz yetkinliği düşük olanların kişisel tehdit olarak gördükleri zor durumlardan kaçındıklarını, amaçlarına ulaşmada isteksiz olduklarını ve bir şeyi nasıl başarılı bir şekilde yapacaklarının yerine kendilerinden şüphe duyduklarını ve başarısızlıktan kaçındıklarını belirtmiştir. Bazı öğretmenlerin öğrencilerinin başaracağına dair olan inançlarının yüksek ve diğerlerinin düşük beklenti içerisinde olmaları, akademik olarak başarısız olan öğrencilerinin sorumluluğunu almamaları ve öğretmen otoritesinden vazgeçmemeleri düşük öğretmen özyeterliliğin bir göstergesi niteliğindedir (Schriver \& Czerniak, 1999). Bu nedenle öğretmenlerin hizmet öncesi eğitimlerinde yetkinlik düzeylerinin belirlenmesi ve buna yönelik bir eğitim verilmesi gerekmektedir. Schunk (1991) öğretmen yetkinliği ile akademik motivasyon arasındaki bağlantıdan söz etmiş ve düşük öğretmen yetkinliğine sahip öğretmenlerin, öğrencilerin gelişimi için gerekli olan etkinlikleri yapmaları için ihtiyaçları olan inanç ve çabayı göstermediklerini, bunun aksine yüksek yeterlik sahibi olanların ise öğrenciler için daha çok çaba sarf ettiği, öğrenme güçlüğü olan öğrenciler için ekstra materyal ve etkinlik hazırladığını (Ashton \& Webb, 1986) bunun da öğrencilerin akademik motivasyonlarını etkilediğini savunmuştur. Buna göre yüksek yetkinliği olan öğretmenlerin yaptıkları davranışlar öğrencilerin akademik motivasyonlarını artırmakta, bunun sonucunda da Bandura'nın (1977) bahsettiği sonuç beklentisinde olduğu gibi, öğretmenlerin yetkinlik düzeyleri de artmaktadır.

Öğretmen yetkinliğinin önemli bir bileşeni olarak nitelendirilebilen motivasyon, bir eylemi yapmak için harekete geçmek olarak tanımlanırken; eylemde istekli olup sürece aktif bir şekilde katılmak isteyenler güdülenmiş veya motivasyonlu, isteksiz olanlar ise güdüsüz veya motivasyonsuz şeklinde ifade edilmektedir (Ryan \& Deci, 2000). Akademik motivasyon ise, öğrencilerin akademik konulara veya etkinliklere yönelik olarak göstermiş oldukları motivasyonu belirtmek için kullanılmaktadır. Alanyazın incelendiğinde akademik motivasyon ve başarı arasındaki ilişkiyi inceleyen çok sayıda çalışma olduğu görülmektedir (An, 2015; Bailey \& Philips, 2016, Calp \& Bacanlı, 2016). Ayrıca literatürde öğretmen yetkinliği ve akademik motivasyon arasında pozitif yönlü bir ilişkinin olduğunu gösteren araştırmalar da yer almaktadır (Kim \& Cho, 2014; Rodriguez, Blas, Valle, Piñeiro \& Cerezo 2014; Saracaloğlu, Kumral \& Kanmaz, 2009).

Bu araştırmada sözü geçen ve öğrencilerin akademik ortamda yerine getirmeleri istenilen ödev ve sorumlulukları zamanında yerine getirmemeleri şeklinde tanımlanan bir diğer kavram da akademik ertelemedir. Steel (2007) öğrencilerin akademik olarak yerine getirmeleri gereken görevleri farklı nedenlerle ertelemelerinin akademik erteleme olarak tanımlandığını ve bunun neden olduğu olumsuz sonuçların dünya genelinde giderek artmakta olduğunu belirtmiştir. Akademik ertelemenin birçok farklı nedeni bulunmaktadır. Bununla ilgili yapılan meta analiz çalışmaları (Kim \& Seo, 2015; Van Eerde, 2003) akademik erteleme ile öz yeterlik, akademik motivasyon ve akademik başarı arasında negatif bir ilişkiyi gösterirken, başarısızlık korkusu, kaçınma ve mükemmeliyetçilik kavramlarıyla pozitif bir ilişkiye işaret etmektedir. Howell ve Watson ise (2007) bilişsel ve üst bilişsel öğrenme strateji kullanımı düşük olan öğrencilerin akademik erteleme düzeylerinin yüksek olduğunu belirtmiştir.

Öte yandan Türkiye'de öğretmen adaylarını yakından ilgilendiren ve devlet kurumlarında öğretmenlik yapabilmeleri için girmeleri gereken hayatlarındaki en önemli sınavlardan biri olan Kamu 
Asuman Seda Saracaloğlu, Beste Dinçer, Muhammed Eken, Sinan Bayık - Uluslararası Eğitim Programlar ve Öğretim Çalışmaları Dergisi, 10 (1), 2020, 53-82

Personeli Seçme Sınavı (KPSS) bu çalışmanın kilit değişkenlerinden biri olarak nitelendirilebilir. Özellikle lisans üçüncü ve dördüncü sınıf öğrencileri için hayatlarının merkezi olarak konumlandırılan bu sınavın birçok öğrencinin psikolojisi üzerinde olumsuz etkileri olduğu ve sınav kaygısına sebep olduğu görülmektedir (Karataş \& Güleş, 2013; Sezgin \& Duran, 2011). Kaygı genel olarak olumsuz düşünceler, olası tehditler veya korkularımıza karşı yaşanılan endişeler olarak algılansa da her zaman yaşanması kötü bir durum değildir. Öğrenmeyi etkileyen duyuşşsal faktörlerden biri olarak orta düzeyde kaygının motivasyon sağlamaya yardımcı olabilirken; düşük ve yüksek kaygı düzeyinin bir takım sorunları beraberinde getirdiği bilinmektedir. Örneğin katılımcı sayısı geniş ölçekli bir araştırmada, Türkiye'de üniversite giriş sınavlarına hazırlanan öğrencilerin sürekli kaygı düzeylerinin, ameliyat olacak hastaların kaygı düzeylerinden daha yüksek olduğu ortaya konmuştur (Ümmet \& Otrar, 2015). Literatürde KPSS'na ilişkin kaygı düzeylerini belirleyen çalışmaların yanı sıra (Çetin, 2013; Ümmet \& Otrar, 2015); KPSS sınav kaygısı ve öğretmenlik mesleği tutumu ilişkisi (Okçu \& Halil, 2009); tükenmişlik ve KPSS kaygı düzeyleri (Köse, Diken \& Gül, 2017; Yavuz \& Akdeniz, 2019) gibi farklı değişkenleri inceleyen çalışmalara rastlanmıştır. Ancak öğretmen adaylarının gelecek meslek yaşamlarıyla doğrudan bağlantılı olan öğretmen yetkinliğini etkileyeceği düşünülen KPSS sınav kaygısı, akademik güdülenme ve akademik erteleme davranışını inceleyen bir çalışmaya rastlanmamıştır.

Bu çalışma kapsamında öğretmen adaylarının öğretmen yetkinlikleri ile akademik güdülenme, Kamu Personel Seçme Sınavı (KPSS) kaygısı ve akademik erteleme düzeyleri arasındaki ilişkinin incelenmesi amaçlanmıştır. Öğretmenlerin hizmet öncesi eğitimleri sırasında, yetkinliklerini etkileyen faktörlerin belirlenmesi ve buna uygun olarak gerekli müdahalelerin yapılabilmesi için bu tür araştırmaların yapılması önem taşımaktadır. Bu doğrultuda aşağıdaki sorulara cevap aranmıştır:

1. Öğretmen adaylarının öğretmen yetkinlik, akademik güdülenme, akademik erteleme ve KPSS kaygı düzeyleri nasıldır?

2. Öğretmen adaylarının öğretmen yetkinlik, akademik güdülenme, akademik erteleme ve KPSS kaygı düzeyleri;

2.1. Cinsiyete,

2.2. Lisans programına,

2.3. Sınıf düzeyine göre farklılık göstermekte midir?

3. Öğretmen yetkinlik, akademik güdülenme, akademik erteleme ve KPSS kaygı düzeyleri arasında nasıl bir ilişki vardır?

4. Öğretmen adaylarının, öğretmen yetkinlik düzeylerini anlamlı olarak yordayan değişkenler nelerdir?

\section{Yöntem}

\section{Araştırmanın Deseni}

Bu çalışma öğretmen adaylarının öğretmen yetkinlikleri ile akademik erteleme, KPSS kaygıları ve akademik motivasyonları arasındaki ilişki incelendiği için iki veya daha fazla değişken arasındaki ilişkileri belirlemede kullanılan (Karasar, 2009) ilişkisel tarama modeline göre desenlenmiştir.

\section{Çalışma Grubu}

Bu araştırmada katılımcılar amaçlı örnekleme yöntemlerinden kolay ulaşılabilir uygun durum örneklemesi ile belirlenmiştir. Kolay ulaşılabilir uygun durum örneklemesi, araştırma yapılacak grupların sürece daha kolaylıkla dâhil edilmesi veya bu gruplara daha kolay bir şekilde ulaşılabilir olmasıyla ilişkilidir ve bu sayede araştırmacıya hız ve pratiklik kazandırma imkânı tanır (Ekiz, 2015; Yıldırım \& Şimşek, 2013). Araştırmanın çalışma grubunu Ege bölgesinde yer alan bir devlet üniversitesinin eğitim fakültesi resim, sınıf ve sosyal bilgiler öğretmenliği programlarındaki üçüncü ve 
Asuman Seda Saracaloğlu, Beste Dinçer, Muhammed Eken, Sinan Bayık - Uluslararası Eğitim Programlar ve Öğretim Çalışmaları Dergisi, 10 (1), 2020, 53-82

dördüncü sınıfta öğrenim gören 187 öğretmen adayı oluşturmaktadır. Araştırmada 109 (\%58) kadın, 42 (\%42) erkek katılımcı yer almaktadır. Ayrıca katılımcıların 84'ü (\%45) üçüncü sınıftadır, 103'ü (\%55) ise dördüncü sınıftadır. Öğretmen adaylarının öğrenim gördükleri programlara bakıldığındaysa 83'ünün Sosyal Bilgiler Öğretmenliği, 54'ünün Sınıf Öğretmenliği, 50'sinin de Resim Öğretmenliği programlarında olduğu görülmektedir.

\section{Veri Toplama Araçları}

Araştırmada veriler katılımcıların yaş, cinsiyet, bölüm ve sınıf düzeyleri gibi bilgilerini almak için oluşturulan kişisel bilgi formuna ek olarak dört veri toplama aracı ile toplanmıştır.

Ohio Öğretmen Yetkinlik Ölçeği: Ohio Öğretmen Yetkinlik ölçeği, Tschannen-Moran ve Woolfolk-Hoy (2001) tarafından öğretmenlerin yetkinlik düzeylerini belirlemek için geliştirilmiş ve Baloğlu ve Karadağ (2008) tarafından Türk dili ve kültürüne uyarlaması yapılmıştır. Uyarlanan ölçek 24 madde ve 5 alt boyuttan oluşmakta olup 5'li likert tipindedir. Ölçeğin iç tutarlık kat sayısı Cronbach Alpha 0.80 olarak bulunmuştur. Bu araştırmada ise ölçeğin iç tutarlılık kat sayısı 0,93 olarak hesaplanmıştır.

Akademik Güdülenme Ölçeği: Bozanoğlu tarafından (2004) ortaöğretim öğrencilerinin akademik güdülenme düzeylerini belirlemek amacıyla geliştirilmiştir. Ölçek üç alt boyuttan ve $5^{\prime} l i$ likert tipi 20 sorudan oluşmaktadır. Ölçeğin iç tutarlık katsayısı Cronbach Alpha aynı grupta farklı zamanlarda .77 den $.85^{\prime}$ e, farklı gruplarda $.77^{\prime}$ den $.86^{\prime}$ ya değiştiği görülmüştür. Bu araştırmada ise ölçeğin iç tutarlılık kat sayısı .87 olarak hesaplanmıştır.

Akademik Erteleme Ölçeği: Çakıcı (2003) tarafından öğrencilerin akademik erteleme davranışlarını ortaya çıkarmak için geliştirilen bu ölçek 19 madde ve iki alt boyuttan oluşmakta olup 5'li likert tipindedir. Çakıcı ölçeğin tek boyut olarak da kullanılabileceğini belirttiği için bu çalışmada tek boyutlu olarak kullanıımıştır. Araştırmada ölçeğin iç tutarlılık katsayısı Cronbach Alpha .92 olarak bulunmuştur. $\mathrm{Bu}$ araştırmada ise ölçeğin iç tutarlılık kat sayısı .83 olarak bulunmuştur.

Kamu Personel Seçme Sınavı Kaygı Ölçeği: Ölçek, Karaçanta (2009) tarafından Kamu Personel Seçme Sınavına (KPSS) girecek olan öğretmen adaylarının sınava yönelik kaygı düzeylerini ölçmek amacıyla oluşturulmuştur. Bu ölçek 19 madde ve 4 alt boyuttan oluşmakta olup 5'li likert tipindedir. Yapılan açımlayıcı faktör analizi sonuçlarına göre ölçeğin geçerli bir veri toplama aracı olduğu görülmüştür. Ölçeğin iç tutarlık kat sayısı Cronbach Alpha .88 olarak bulunmuştur. Bu araştırmada ise ölçeğin iç tutarlııı kat sayısı .81 olarak hesaplanmıştır.

\section{Veri Toplama Süreci}

Araştırma verileri 2016-2017 akademik yılında bahar döneminde bir devlet üniversitesinde araştırmacılar tarafından toplanmıştır. Araştırmada kullanılan ölçekler basılı formlar halinde gönüllü öğrencilere dağıtılmış ve verilen formlar yaklaşık 10-15 dakika arasında doldurulmuştur

\section{Veri Analizi}

Katılımcılardan toplanan veriler araştırmacılar tarafından elektronik ortamda kodlanmış ve veriler bir paket program aracılığıyla analiz edilmiştir. Araştırma verileri 203 katılımcı tarafından cevaplandırılmıştır. Fakat veriler kontrol edildiğinde 10 katılımcının ölçekleri yarım bıraktıkları veya özensiz kodladıkları görülmüştür. Ayrıca 6 katılımcının da cevaplarının aşııı uç değerlerde olduğu için veri setinden bu 16 katılımcı çıkarılmıştır. Analizlerde parametrik testlerin uygulanıp uygulanmayacağını belirlemek için verilerin normal dağılıp dağılmadığı kontrol edilmiştir. Normallik varsayımları, basıklık ve çarpıklık değerlerinin hata değerlerine oranlarına bakılarak kontrol edilmiş ve değerlerin -1.00 ile +1.00 arasında yer aldıkları görülmüştür. Verilerin çoklu normallik durumunu incelemek için Mahalanobis uzaklık katsayısına ve saçılım diyagramına bakılmıştır. Değişkenlerin Mahalanobis uzaklık değeri katsayısının maksimum 13.551 olduğu tespit edilmiş ve çoklu normallik özelliğinin sağlandığı görülmüştür. Ayrıca çoklu bağlantı olup olmadığını kontrol etmek için bağımsız değişkenlerin VIF değerlerine bakıldığında değerlerin 1.017 ile 1.052 arasında olduğu, tolerans 
Asuman Seda Saracaloğlu, Beste Dinçer, Muhammed Eken, Sinan Bayık - Uluslararası Eğitim Programlar ve Öğretim Çalışmaları Dergisi, 10 (1), 2020, 53-82

değerlerinin $(\mathrm{Cl}) 15$ 'den yüksek olmadığı görülmüştür. Son olarak da değişkenler arasındaki otokorelasyonu incelemek için Durbin Watson katsayısına bakılmıştır. Durbin Watson katsayısının 2.00 olduğu görülmüş ve bu değerin Field (2005) tarafından eşik değer olarak gösterilen 1.5-2.5 arasında olduğu belirlenmiştir. Analizler için gerekli varsayımlar kontrol edildikten sonra öğretmen adaylarının öğretmen yetkinlik, akademik güdülenme, akademik erteleme ve kpss kaygı düzeyleri ile cinsiyet ve sınıf düzeyi değişkenleri arasındaki ilişki bağımsız gruplar t-testi, söz konusu değişkenlerin kayıtlı olunan program ile ilişkisi tek yönlü varyans analizi ile sınanmıştır. Ek olarak bağımlı değişkenlerinin kendi aralarındaki ilişkiyi belirlemek amacıyla Pearson korelasyon analizi ve bağımsız değişkenlerin birlikte öğretmen adaylarının öğretmen yetkinliklerini yordamasına ilişkin çoklu regresyon analizleri yapılmış ve bulgularda sunulmuştur.

\section{Bulgular}

Araştırmanın bu bölümünde; araştırmanın alt problemlerinin çözümlenebilmesi amacıyla toplanan verilerin analiz edilmesi ile elde edilen bulgulara yer verilmiştir.

\section{Öğretmen Adaylarının Öğretmen Yetkinlik, Akademik Güdülenme, Akademik Erteleme ve KPSS Kaygı Düzeyleri}

Öğretmen adaylarının öğretmen yetkinlik, akademik güdülenme, akademik erteleme ve KPSS kaygı düzeylerine ilişkin ölçek toplam ve alt boyutlardan alınan ortalama puanları Tablo 1, 2, 3 ve 4'te gösterilmiştir.

Tablo 1.

Öğretmen Adaylarının Öğretmen Yetkinlik, Akademik Güdülenme, Akademik Erteleme ve KPSS Kaygı Düzeyleri

\begin{tabular}{lccc}
\hline Değişkenler & $\mathbf{N}$ & $\overline{\mathbf{X}}$ & Ss \\
\hline Akademik Erteleme & 187 & 2.981 & .523 \\
KPSS Kaygı & 187 & 2.790 & .612 \\
Akademik Güdülenme & 187 & 3.151 & .574 \\
Öğretmen Yetkinliği & 187 & 3.730 & .621 \\
\hline
\end{tabular}

Tablo 1'e bakıldığında öğretmen adaylarının akademik güdülenme $(\bar{X}=3.15)$ ve öğretmen yetkinlik $(\bar{X}=3.73)$ düzeylerinin yüksek olduğu, KPSS kaygılarının $(\bar{X}=2.79)$ ve akademik erteleme $(\bar{X}=2.98)$ düzeylerinin ise orta düzeye yakın olduğu görülmektedir.

Tablo 2.

Öğretmen Adaylarının Öğretmen Yetkinlik Düzeyleri

\begin{tabular}{lccc}
\hline Alt boyutlar & $\mathbf{N}$ & $\overline{\mathbf{X}}$ & Ss \\
\hline Davranış Yönetimi & 187 & 3.71 & .668 \\
Motivasyon & 187 & 3.80 & .701 \\
Öğretim Becerisi & 187 & 3.70 & .717 \\
Ölçme ve Değerlendirme & 187 & 3.67 & .782 \\
Toplam & 187 & 3.72 & .621 \\
\hline
\end{tabular}

Tablo 2'de öğretmen adaylarının öğretmen yetkinliklerinin alt boyutlarına bakıldığında en yüksek ortalamaya motivasyon ( $\bar{X}=3.80)$ alt boyutunda, en düşük ortalamaya ise ( $\bar{X}=3.67)$ ölçme ve değerlendirme alt boyutunda sahip oldukları görülmektedir.

Tablo 3.

Öğretmen Adaylarının KPSS Kaygı Düzeyleri

\begin{tabular}{lccc}
\hline Alt boyutlar & $\mathbf{N}$ & $\overline{\mathbf{X}}$ & Ss \\
\hline Genel Kaygı & 187 & 2.55 & .742 \\
Başkalarının Endişesi & 187 & 2.72 & .806 \\
Gelecekle İlgili Endişe & 187 & 3.36 & .915 \\
Sınava Hazırlık & 187 & 3.01 & .894 \\
Toplam & 187 & 2.79 & .612 \\
\hline
\end{tabular}


Asuman Seda Saracaloğlu, Beste Dinçer, Muhammed Eken, Sinan Bayık - Uluslararası Eğitim Programlar ve Öğretim Çalışmaları Dergisi, 10 (1), 2020, 53-82

Tablo 3 incelendiğinde öğretmen adaylarının KPSS kaygı ölçeğinin alt boyutlarından aldıkları puanlar görülmektedir. En yüksek kaygı düzeylerinin gelecekle ilgili endişe alt boyutunda olduğu, en düşüğün ise genel kaygı ( $\bar{X}=2.55)$ boyutunda olduğu görülmüştür.

Tablo 4.

Öğretmen Adaylarının Akademik Güdülenme Düzeyleri

\begin{tabular}{lccc}
\hline Alt boyutlar & $\mathbf{N}$ & $\overline{\mathbf{X}}$ & Ss \\
\hline Bilgiyi Kullanma & 187 & 2.55 & .742 \\
Kendini Aşma & 187 & 2.72 & .806 \\
Keşif & 187 & 3.36 & .915 \\
Toplam & 187 & 2.79 & .612 \\
\hline
\end{tabular}

Tablo 4 incelendiğinde öğretmen adaylarının akademik güdülenme ölçeğinin alt boyutlarından aldıkları puan ortalamaları görülmektedir. En yüksek puan ortalamasının yeni bir şeyler keşfetmeye yönelik motivasyonları olan keşif alt boyutunda $(\bar{X}=3.36)$ olduğu, en düşük ortalamanın ise bilgiyi kullanma alt boyutunda ( $\bar{X}=2.55)$ olduğu göze çarpmaktadır.

\section{Cinsiyet Değişkenine İlişkin Bulgular}

Katılımcıların cinsiyetinin akademik erteleme, akademik güdülenme, KPSS kaygıSı ve öğretmen yetkinliği üzerinde bir etkisinin olup olmadığını ortaya çıkarmak için bağımsız değişkenler t-testi analizi yapılmıştır.

Tablo 5.

Öğretmen Adaylarının Cinsiyetine Göre Bağımsız Gruplar T-Testi Sonuçları

\begin{tabular}{llccccc}
\hline Değişkenler & Cinsiyet & $\mathbf{N}$ & $\overline{\boldsymbol{X}}$ & Ss & $\boldsymbol{t}$ & $\boldsymbol{p}$ \\
\hline \multirow{2}{*}{ Akademik Erteleme } & Kadın & 109 & 2.93 & 0.592 & \multirow{2}{*}{-1.514} & 0.132 \\
& Erkek & 78 & 3.04 & 0.523 & & \\
\multirow{2}{*}{ Akademik Güdülenme } & Kadın & 109 & 3.68 & 0.535 & -1.434 & 0.153 \\
& Erkek & 78 & 3.80 & 0.576 & & \\
\multirow{2}{*}{ KPSS Kaygı } & Kadın & 109 & 2.76 & 0.589 & -0.825 & 0.410 \\
& Erkek & 78 & 2.83 & 0.643 & & \\
\multirow{2}{*}{ Öğretmen Yetkinliği } & Kadın & 109 & 3.76 & 0.575 & \multirow{2}{*}{0.705} & 0.482 \\
& Erkek & 78 & 3.69 & 0.681 & &
\end{tabular}

Tablo 5 incelendiğinde öğretmen adaylarının ölçme araçlarından elde ettikleri puanlara ilişkin yapılan bağımsız gruplar T-testi sonuçları görülmektedir. Buna göre öğretmen adaylarının, akademik erteleme, akademik güdülenme, KPSS kaygı ve öğretmen yetkinlik ölçeklerinden aldıkları puanlar cinsiyete göre anlamlı bir farklılık göstermediği tespit edilmiştir.

\section{Sınıf Değişkenine ilişkin Bulgular}

Katılımcıların sınıf değişkeninin akademik erteleme, akademik güdülenme, KPSS kaygıSı ve öğretmen yetkinliği üzerinde bir etkisinin olup olmadığını ortaya çıkarmak için bağımsız değişkenler tTesti analizi yapılmıştır. Tablo 6 incelendiğinde öğretmen adaylarının ölçme araçlarından aldıkları puanların sınıf düzeylerine göre farklılığına ilişkin t-testi sonuçları görülmektedir.

Tablo 6.

Öğretmen Adaylarının Sınıf Düzeylerine Göre Bağımsız Gruplar T-Testi Sonuçları

\begin{tabular}{llccccc}
\hline Değişkenler & Sınıf & $\mathbf{N}$ & $\overline{\boldsymbol{X}}$ & Ss & $\boldsymbol{t}$ & $\boldsymbol{p}$ \\
\hline \multirow{2}{*}{ Akademik Erteleme } & 3. sınıf & 84 & 2.98 & .576 & 0.001 & 0.999 \\
& 4. sınıf & 103 & 2.98 & .478 & & \\
Akademik Güdülenme & 3. sınıf & 84 & 3.64 & .553 & -2.203 & $0.029^{*}$
\end{tabular}


Asuman Seda Saracaloğlu, Beste Dinçer, Muhammed Eken, Sinan Bayık - Uluslararası Eğitim Programlar ve Öğretim Çalışmaları Dergisi, 10 (1), 2020, 53-82

Tablo 6 (Devamı)

\begin{tabular}{lcccccc} 
KPSS Kaygı & 3. sınıf & 84 & 2.73 & .557 & -1.231 & 0.220 \\
\multirow{2}{*}{ Öğretmen Yetkinliği } & 4. sınıf & 103 & 2.84 & .652 & & \\
& $3 . \operatorname{sın}$ If & 84 & 3.74 & .620 & 0.268 & 0.789 \\
\hline
\end{tabular}

Tablo 6'ya göre öğretmen adaylarının akademik erteleme, KPSS kaygı ve öğretmen yetkinlik düzeyleri arasında istatistiksel olarak anlamlı bir farklılık olmadığı gözükürken; akademik güdülenme düzeylerinin ( $\mathrm{t}=-2.203, p=0.029)$ 4. sınıf öğrencileri lehine anlamlı olarak farklılaştığı bulunmuştur. Bunun üzerine akademik güdülenme ölçeğinin hangi alt boyutlarında farklılık olduğunu görmek için ttesti yapılmış ve Tablo 7'de sunulmuştur.

Tablo 7.

Öğretmen Adaylarının Akademik Motivasyon Puanlarının Sınıf Düzeylerine Göre T-Testi Sonuçları

\begin{tabular}{|c|c|c|c|c|c|c|}
\hline Alt boyutlar & Sinıf & $\mathbf{N}$ & $\bar{x}$ & Ss & $T$ & $p$ \\
\hline \multirow{2}{*}{ Bilgiyi kullanma } & 3.sınıf & 84 & 3.92 & 0.60 & \multirow{2}{*}{-1.291} & \multirow{2}{*}{0.198} \\
\hline & 4.sınif & 103 & 4.04 & 0.66 & & \\
\hline \multirow{2}{*}{ Kendini aşma } & 3.sinıf & 84 & 3.57 & 0.70 & \multirow{2}{*}{-2.216} & \multirow{2}{*}{$0.036^{*}$} \\
\hline & 4.sinıf & 103 & 3.78 & 0.66 & & \\
\hline \multirow{2}{*}{ Keşif } & 3.sın If & 84 & 3.46 & 0.64 & \multirow{2}{*}{-2.146} & \multirow{2}{*}{$0.033^{*}$} \\
\hline & 4.sinıf & 103 & 3.65 & 0.59 & & \\
\hline \multirow{2}{*}{ Toplam } & 3.sınıf & 84 & 3.64 & 0.55 & \multirow{2}{*}{-2.203} & \multirow{2}{*}{$0.029 *$} \\
\hline & 4.sinif & 103 & 3.81 & 0.54 & & \\
\hline
\end{tabular}

$* \overline{p<.05}$

Tablo 7 incelendiğinde öğretmen adaylarının sınıf düzeyine göre akademik güdülenme ölçeğinin bilgiyi kullanma alt boyutunda istatistiksel olarak anlamlı bir şekilde farklılık bulunmazken; kendini aşma ( $t=-2.216, p=0.036)$ ve keşif $(t=-2.146, p=0.033)$ alt boyutlarında istatistiksel olarak anlamlı bir farklılık olduğu görülmüştür. Bu durum dördüncü sınıflar lehinedir.

\section{Bölüm Değişkenine iliş̧kin Bulgular}

Katılımcıların bölüm değişkeninin akademik erteleme, akademik güdülenme, KPSS kaygıSı ve öğretmen yetkinliği üzerinde bir etkisinin olup olmadığını ortaya çıkarmak için tek yönlü varyans analizi yapılmıştır.

Tablo 8.

Kayıtlı Olunan Programa İlişkin Tek Yönlü Varyans Analizi Değerleri

\begin{tabular}{llccccc}
\hline Değişkenler & Varyansın kaynağı & Kareler Toplamı & Sd & Ortalama kare & F & $\boldsymbol{P}$ \\
\hline \multirow{2}{*}{ Akademik } & Gruplar arası & .111 & 2 & .056 & & \\
Erteleme & Grup içi & 50.789 & 184 & .276 & 0.202 & 0.818 \\
& Toplam & 50.900 & 186 & & & \\
Akademik & Gruplar arası & .985 & 2 & .493 & & 0.202 \\
Güdülenme & Grup içi & 56.137 & 184 & .305 & 1.614 & \\
& Toplam & 57.122 & 186 & & & \\
& Gruplar arası & .846 & 2 & .423 & & 0.325 \\
KPSS Kaygı & Grup içi & 68.824 & 184 & .374 & 1.131 & \\
& Toplam & 69.670 & 186 & & & \\
Öğretmen & Gruplar arası & .359 & 2 & .179 & & 0.631 \\
Yetkinliği & Grup içi & 71.451 & 184 & .388 & 0.462 & \\
& Toplam & 71.809 & 186 & & & \\
\hline
\end{tabular}


Asuman Seda Saracaloğlu, Beste Dinçer, Muhammed Eken, Sinan Bayık - Uluslararası Eğitim Programlar ve Öğretim Çalışmaları Dergisi, 10 (1), 2020, 53-82

Tablo 8'de öğretmen adaylarının kayıtlı oldukları programa yönelik ölçme araçlarından aldıkları puanların tek yönlü varyans analizi sonuçları verilmiştir. Tablo incelendiğinde kayıtlı olunan program değişkenine göre akademik erteleme $(F=0.202, p=0.818)$, akademik güdülenme $(F=1.614, p=0.202)$, KPSS kaygı ( $F=1.131, p=0.325)$ ve öğretmen yetkinliği $(F=0.462, p=0.631)$ düzeylerinin kayıtlı olunan program türüne göre istatistiksel olarak anlamlı bir farklılık olmadığı görülmektedir.

\section{Katılımcıların Akademik Güdülenme, Akademik Erteleme, Öğretmen Yetkinlikleri ve KPSS Kaygı Düzeyleri Arasındaki iliş̧ki}

Araştırmanın bağımlı değişkenlerinin kendi aralarındaki ilişkiyi belirlemek amacıyla yapılan Pearson korelasyon katsayısına ilişkin sonuçlar aşağıda Tablo 9'da sunulmuştur.

Tablo 9.

Öğretmen Yetkinlik, Akademik Güdülenme, Akademik Erteleme ve KPSS Kaygı Düzeyleri Arasındaki Ilişki

\begin{tabular}{lcccc}
\hline Değişkenler & $\begin{array}{c}\text { Akademik } \\
\text { erteleme }\end{array}$ & $\begin{array}{c}\text { Akademik } \\
\text { güdülenme }\end{array}$ & KPSS Kaygı & $\begin{array}{c}\text { Öğretmen } \\
\text { yetkinliği }\end{array}$ \\
\hline Akademik Erteleme & 1 & & & \\
Akademik Güdülenme & $-0.20^{*}$ & 1 & & \\
KPSSKaygı & 0.09 & 0.08 & 1 & 1 \\
Öğretmen Yetkinliği & $-0.19^{*}$ & $0.46^{*}$ & -0.02 & 1 \\
\hline${ }^{*}{ }_{p<0,01}$ & & & &
\end{tabular}

Tablo 9 incelendiğinde öğretmen adaylarının akademik erteleme, akademik güdülenme, KPSS kaygı ve öğretmen yetkinlik düzeyleri arasındaki ilişki gösterilmektedir. Buna göre öğretmen adaylarının akademik erteleme düzeyleri ile akademik güdülenmeleri $(\mathrm{R}=-0.20, p=0.007)$ ve öğretmen yetkinlikleri $(\mathrm{R}=-0.19, p=0.008)$ arasında negatif yönlü zayıf bir ilişki olduğu görülmüştür. Buna göre öğretmen adaylarının erteleme düzeyleri artarken akademik güdülenmeleri ve öğretmen yetkinlikleri azalmaktadır, tersi durum için de geçerlidir. Ayrıca, akademik güdülenme ile öğretmen yetkinlikleri arasında da pozitif yönlü ve orta düzey bir ilişki $(\mathrm{R}=0.46, p=0)$ olduğu görülmüştür.

\section{Öğretmen Adaylarının, Öğretmen Yetkinlik Düzeylerini Yordayan Değişkenler}

Öğretmen adaylarının öğretmen yetkinlik düzeylerini yordayan değişkenlere ilişkin yapılan çoklu regresyon analizi sonuçları Tablo 10'da sunulmuştur.

Tablo 10.

Bağımsız Değişkenlerin Birlikte Öğretmen Adaylarının Öğretmen Yetkinliklerini Yordamasına Illişkin Çoklu Regresyon Analizi Sonuçları

\begin{tabular}{lccccccccc}
\hline Değişkenler & B & $\begin{array}{c}\text { Std. } \\
\text { Hata }\end{array}$ & B & $\boldsymbol{T}$ & $\boldsymbol{P}$ & Tolerans & VIF & Cl & \%95 GA \\
\hline $\begin{array}{l}\text { (Sabit) } \\
\text { Akademik }\end{array}$ & 2.341 & 0.421 & & 5.558 & 0.000 & & & 1 & $1.510 / 3.172$ \\
$\begin{array}{l}\text { Erteleme } \\
\text { Akademik }\end{array}$ & -0.118 & 0.079 & -0.100 & -1.495 & 0.137 & 0.950 & 1.052 & 10.493 & $-0.274 / 0.038$ \\
$\begin{array}{l}\text { Güdülenme } \\
\text { KPSS kayg। }\end{array}$ & 0.502 & 0.075 & 0.447 & 6.720 & 0.0 & 0.952 & 1.050 & 11.369 & $0.354 / 0.649$ \\
\hline \multicolumn{2}{l}{ Yetkinlik=2,341-0,118xAE+0,502xAG-0,047xKK } & 0.067 & -0.047 & -0.713 & 0.48 & 0.983 & 1.017 & 24.668 & $-0.179 / 0.084$ \\
\hline
\end{tabular}

Tablo 10'da öğretmen adaylarının akademik erteleme, akademik güdülenme ve KPSS kaygı düzeylerinin öğretmen yetkinlik düzeylerini hangi yönde ve ne düzeyde açıkladığını belirlemek amacıyla çoklu regresyon analizi verilmiştir. Çoklu regresyon analizi sonucuna göre oluşturulan modelin bütün olarak geçerli olmadığı $(F(3.183)=17.966 ; p<0,001)$ ve bağımsız değişkenlerin, öğretmen yetkinliğine ait açıklanan toplam varyansın $\% 22^{\prime} \operatorname{sini}\left(R^{2}=0.22\right)$ açıkladığı belirlenmiştir. Çoklu regresyon modeline ilişkin parametreler incelendiğinde standardize edilmiş regresyon katsayıları ( $\beta$ ), yordayıcı değişkenlerin akademik öz yeterlilikleri üzerindeki önem sırasının; akademik güdülenme $(\beta=0.447 ; t=$ 
6.720; $p<0.01)$, KPSS kaygı ( $\beta=-0.047 ; t=-0.713 ; p<0.05)$ ve akademik erteleme $(\beta=-0.100 ; t=-1.495$; $p>0.5$ ) olduğunu göstermektedir. Bütün değişkenler ele alındığında akademik güdülenme ve KPSS kaygılarının öğretmen yetkinliğinin anlamlı birer yordayıcısı olduğu, akademik erteleme düzeylerinin ise anlamlı bir yordayıcısı olmadığı ortaya çıkmıştır. Ayrıca çoklu regresyon analizinde bağımsız değişkenlere ait B değerlerinin tümünün \%95 güven aralığının içinde kaldıkları belirlenmiştir.

\section{Tartışma, Sonuç ve Öneriler}

Gerçekleştirilen araştırma sonucunda, öğretmen adaylarının akademik güdülenme ve öğretmen yetkinlik düzeyleri ortalama puanlarının yüksek düzeyde olduğu belirlenirken, akademik erteleme ve KPSS kaygı ortalama puanlarının daha orta düzeyde olduğu belirlenmiştir. Bunun yanı sıra öğretmen adaylarının öğretmen yetkinlikleri alt boyutları irdelendiğinde en yüksek puanı motivasyon alt boyutundan aldıkları belirlenirken, en düşük puan ölçme ve değerlendirme boyutunda karşımıza çıkmaktadır. Mevcut çalışmada öğretmen adaylarının yüksek düzeyde akademik güdülenme, motivasyon ve yetkinliğe sahip olmaları genel anlamda öğretmenliğe ilişkin duyuşsal özelliklerin gelişimine dair ipuçlarına işaret ettiği için istendik bir bulgu özelliği taşımaktadır.

Benzer çalışma sonuçlarına göre de öğretmen adaylarının öğretmen yetkinlik algılarının üst seviyelerde olduğu görülmektedir (İpek \& Demirel, 2012; Özaydınlık, 2018). Vural ve Gündüz (2019) tarafından yapılan araştırmada da öğretmen adaylarının "orta" düzeyde akademik erteleme davranışı gösterdikleri bulunmuştur. KPSS sınav kaygısına ilişkin ortalama puanların bu çalışmada orta düzey olduğu belirlenirken farklı grup öğretmen adaylarında (Ekici \& Kurt, 2012; Köse, Diken \& Gül, 2017; Yavuz \& Akdeniz, 2019) tarafından yapılan çalışma sonuçlarının birbirini destekler nitelikte olduğu görülmektedir.

Cinsiyet değişkeni çerçevesinde akademik erteleme, akademik güdülenme, KPSS kaygıSı ve öğretmen yetkinlik ölçek puanlarına göre öğretmen adayları arasında anlamlı bir farklılık bulunmamıştır. Başka bir ifadeyle bu çalışmada kadın ve erkek öğretmen adayları benzer puanlara sahiptirler ve cinsiyet belirleyici bir değişken değildir. Gündoğdu, Çimen ve Turan (2008) öğretmen adaylarının KPSS kaygılarını inceledikleri araştırmalarında benzer olarak cinsiyetin anlamlı bir farklılık yaratmadığını saptamışlardır. Buna karşın ilgili alanyazında yapılan çalışma sonuçlarına göre farklı sonuçlar dikkat çekmektedir. Örneğin bazı çalışmalarda erkek öğretmen adaylarının (Balkıs \& Duru, 2009; Demir \& Ferrari, 2009; Dinçer \& Gerçeker, 2018; Gökdere \& Çakır, 2015; Uzun Özer, Demir \& Ferrari, 2009; Vural \& Gündüz, 2019); bazı çalışmalarda da kadın öğretmen adaylarının daha yüksek akademik erteleme düzeyine sahip olduğu göze çarpmaktadır (Mişe \& Hançer, 2019; Özer \& Ferrari, 2011). Buna karşın eldeki çalışmaya benzer olarak Çıkrıkçı ve Erzen (2016) cinsiyetin akademik ertelemede belirleyici bir etken olup olmadığını inceledikleri meta analiz çalışmasında, anlamlı bir farklılık elde etmemişlerdir.

Akademik güdülenme düzeyi ile ilgili Şahin ve Çakar (2011) tarafından gerçekleştirilen çalışmada cinsiyet öğretmen adaylarının akademik güdülenme düzeylerinde anlamlı bir farklıık yaratmamıştır; ancak okunan bölümler arasında istatistiksel olarak anlamlı bir fark olduğu belirtilmiştir. Aynı şekilde Demir ve Arı (2013) çalışmalarında da öğretmen adaylarının akademik güdülenme düzeyleri arasında cinsiyete göre anlamlı bir farklılık oluşmaz iken okunan bölümlere göre istatistiksel olarak anlamlı bir fark olduğu belirtilmiştir. Buna karşın Gerçeker ve Şeker (2013) çalışmasında müzik eğitimi bölümü öğretmen adayları ile akademik güdülenme alt boyutlarında eldeki çalışma ile paralel şekilde bilgiyi kullanma alt boyutu lehine anlamlı bir farklılık bulunmuştur. Aktaş (2017), ilahiyat fakültesi öğrencileriyle yaptığı çalışmada cinsiyetin öğrencilerin akademik güdülenme düzeylerinde anlamlı bir farklıık yaratmadığını ortaya koymuştur. Bu yönüyle ilgili çalışmalar araştırma sonuçları ile örtüşmektedir.

KPSS kaygı düzeyine ilişkin gerçekleştirilen Karaçanta ve Koç (2015) çalışmalarında KPSS kaygısı ile ilgili olarak cinsiyet değişkeninin KPSS kaygısının pozitif bir yordayıcıSı olduğu, erkeklerin kaygı 
Asuman Seda Saracaloğlu, Beste Dinçer, Muhammed Eken, Sinan Bayık - Uluslararası Eğitim Programlar ve Öğretim Çalışmaları Dergisi, 10 (1), 2020, 53-82

düzeyinin korelasyonel olarak kadınların kaygı düzeyinden daha düşük olduğu sonucuna ulaşmıştır. Benzer şekilde Köse, Diken ve Gül'ün (2017) biyoloji öğretmen adayları ile farklı bir ölçekle gerçekleştirilen kaygı ile ilgili çalışmasında da cinsiyete göre farklılık olduğu sonucuna ulaşılmıştır. Akademik erteleme davranışı ile ilgili olarak Bulut (2014) yüksek lisans tez çalışmasında sosyal bilgiler öğretmen adaylarının akademik erteleme davranışında cinsiyete ve sınıf seviyesine göre istatistiksel olarak anlamlı farklar olduğu sonucuna ulaşmıştır. Benzer şekilde Gerçeker ve Şeker (2013) tarafından güzel sanatlar resim-iş ve müzik bölümü öğretmen adayları ile gerçekleştirilen çalışmada cinsiyete, bölüme ve sınıf düzeyine göre anlamlı farklılıklar olduğu belirtilmiştir. Wu ve Fan (2017) akademik erteleme davranışının akademik motivasyonla ilişkili olduğunu ve motivasyon düştükçe erteleme davranışııın arttığını belirtmişlerdir.

Ancak sınıf düzeyi değişkeni incelendiğinde; akademik erteleme, KPSS kaygı ve öğretmen yetkinlik düzeyleri arasında anlamlı bir fark belirlenmemesine rağmen, akademik güdülenme düzeyinde kendini aşma ve keşif alt boyutlarında anlamlı bir farklılık olduğu görülmektedir. Bu durum sınıf düzeyi ilerledikçe öğretmen adaylarının kendilerini öğretmenlik mesleğine daha yakın hissettikleri dolayısıyla da akademik anlamda daha fazla güdülendikleri anlamına gelmektedir. Terzi, Ünal ve Gürbüz (2012) araştırmalarında 4.sınıf öğrencilerinin akademik güdülenme düzeylerinin 2. sınıf öğrencilerinin akademik güdülenme düzeylerinden daha yüksek olduğunu ortaya koymuşlardır. Benzer şekilde Terzi, Uyangör ve Dülker (2017) çalışmalarında formasyon eğitimi alan mezun öğretmen adaylarının akademik güdülenme düzeylerinde son sınıfta okuyan öğrenciler lehine anlamlı bir farklılık saptamışlardır. Öte yandan öğretmen adaylarının akademik erteleme düzeyleri sınıf düzeyi açısından Bulut ve Ocak'ın (2017) çalışmasında bazı alt boyutlarda (sorumsuzluk, öğretmenlere ilişkin olumsuz algı ve akademik mükemmeliyetçilik) anlamlı farklılı̆ın olmadığı; ancak bir boyutta (akademik görevin algılanan niteliğinde) üçüncü ve dördüncü sınıflar ile birinci sınıflar arasında, üçüncü ve dördüncü sınıflar lehine anlamlı fark olduğu ortaya çıkmıştır. Bazı çalışmalarda ise bu araştırmada elde edilen bulgunun aksine öğretmen adaylarının sınıf düzeyleri arttıkça motivasyonlarının önceki yıllara göre azaldığı görülmüştür (Eymur \& Geban, 2011; Gürşimşek, 2002; Uyulgan \& Akkuzu, 2014).

Öğretmen adaylarının kayıtlı bulundukları bölüm değişkeninin ise akademik erteleme, akademik güdülenme, Kpss kaygısı ve öğretmen yetkinliği üzerinde anlamlı bir etkisi olmadığı saptanmıştır. Akademik güdülenmeye ilişkin benzer olarak Terzi, Uyangör ve Dülker (2017); akademik erteleme ile ilgili olarak Vural ve Gündüz (2019); KPSS kaygısına ilişkin Altun, Avcı, Özüpekçe ve Gümüş (2017), Yılmaz ve Yaşar (2016) çalışma sonuçları eldeki çalışma ile tutarlıık göstermektedir. Ek olarak öğretmen adaylarının, öğretmen yetkinliklerinin çeşitli değişkenler çerçevesinde incelendiği benzer çalışmalarda farklı sonuçlara da ulaşıldığı görülmüştür. Tuluk'un (2014) çalışmasında farklı bölümlere göre öğretmen yetkinliğinde anlamlı farklılıklar bulunduğu görülmektedir. Benzer şekilde Demirtaş, Cömert ve Özer'in (2011) çalışmalarında farklı bir ölçekle gerçekleştirilen öz-yeterlik belirlenmesine yönelik bulgular ölçeğin bazı alt boyutlarında bölüme göre anlamlı farklılıklara işaret etmektedir. Bu açıdan öğretmen adaylarının yetkinliğinin bölümlere göre belirleyici bir etken olmadığı ve çalışılan örneklem grubuna göre değiştiği görülmektedir.

Öğretmen adaylarıın, öğretmen yetkinlik düzeyleri ile akademik erteleme düzeyleri ve akademik güdülenmeleri arasında negatif yönlü zayıf bir korelasyonel ilişki görülmektedir. Buna göre öğretmen adaylarının akademik erteleme düzeyleri artarken akademik güdülenme düzeyleri ve öğretmen yetkinlik düzeyleri düşüş göstermektedir. Bunun yanı sıra öğretmen adaylarının akademik güdülenme düzeyi ile öğretmen yetkinlikleri arasında orta düzeyde pozitif yönlü bir ilişki olduğu görülmektedir. Bu durum öğretmen adaylarının akademik anlamda güdülenme düzeylerinin artmasıyla birlikte öğretmen yetkinliklerinin de olumlu yönde etkilendiği ve akademik erteleme düzeylerinin de düşüş gösterdiğine işaret etmektedir. Benzer şekilde Saracaloğlu ve Dinçer (2009) öğretmen adaylarının öğretmen özyetkinlik düzeyleri ve akademik güdülenmeleri arasında orta düzeyde bir ilişki ortaya koymuştur. Saracaloğlu, Kumral \& Kanmaz (2009) sosyal bilgiler öğretmen adayları ile gerçekleştirdiği çalışmasında adayların mesleki yeterlik algıları ile akademik güdülenmeleri arasında pozitif ve anlamlı bir ilişki 
olduğunu ortaya koymuştur. Alemdağ, Öncü ve Yılmaz (2014) beden eğitimi öğretmen adayları ile gerçekleştirdiği benzer bir çalışmada akademik güdülenmenin akademik öz-yeterlik üzerine pozitif etkisini belirtmiştir.

Öğretmen adaylarının öğretmen yetkinlik düzeylerinin bağımsız değişkenler olan akademik güdülenme, KPSS kaygı ve akademik erteleme ne ölçüde yordandığına bakıldığında toplam varyansın \%22'lik kısmının açıklandığı görülmektedir. Sırası ile akademik güdülenme düzeyi ve KPSS kaygı düzeyi öğretmen adaylarının öğretmen yetkinlik düzeylerinin anlamlı bir yordayıcısı olarak belirtilebilir. Ek olarak akademik erteleme düzeyinin ise öğretmen yetkinlik düzeyi üzerinde anlamlı bir yordayıcı olmadığı belirlenmiştir. Bu sonuçtan akademik güdülemesi yüksek olan öğretmen adaylarının hedeflerini daha net ortaya koydukları ve bu hedefler çerçevesinde atanıp atanamama kaygısı yaşadıklarından ötürü daha çok çalıştıkları şeklinde yorum çıkarılabilir. Dolayısıyla aldıkları eğitim süresince öğretmen adaylarını motive etmek, öğretmenlik mesleğine ilişkin güdülenmelerini sağlamak; sadece akademik yönden değil duyuşsal olarak da geliştirmek gerekli görülmektedir.

Araştırmanın sonuçlarına dayalı olarak araştırmacılara ve uygulayııılara yönelik aşağıdaki öneriler verilebilir:

Bu çalışma ile akademik güdülenme ve KPSS kaygılarının öğretmen yetkinliğinin anlamlı birer yordayıcısı olduğu ortaya konmuştur. Yapılacak çalışmalarda öğretmen yetkinliğinin birer yordayısı olarak akademik güdülenme kavramı ve benzer şekilde KPSS sınavının öğretmen adayları üzerinde yarattığı kaygının onların mesleki yetkinliklerini nasıl etkilediğine ilişkin deneysel ve nitel çalışmalar yapılabilir. Mesleğinde yetkin ve etkili birer öğretmen olarak yetiştirilmelerini sağlamak adına öğretmen eğitimi veren temel kurumlar olan eğitim fakültelerinde de öğretmen adaylarının akademik güdülenmelerini destekleyici, bilişsel alanın yanı sıra duyuşssal alan kazanımlarını içerisinde barındıran program içerikleri düzenlenebilir. Bununla birlikte sınıf düzeyi ilerledikçe öğretmen adaylarının akademik güdülenme düzeylerinde olumlu artışın yaşanıp yaşanmaması üzerine boylamsal çalışmalar yapılıp sonuçları üzerinde çalışılarak sürecin olumlu yönde ilerlemesi desteklenebilir.

\section{Bilgilendirme}

Bu çalışma 26-28 Ekim 2017 tarihlerinde Muğla, Türkiye'de gerçekleştirilen 5. Uluslararası Eğitim Programları ve Öğretim Kongresi'nde sözlü bildiri olarak sunulmuştur. 
Alemdağ, C., Öncü, E., \& Yılmaz, A. K. (2014). Beden eğitimi öğretmeni adaylarının akademik motivasyon ve akademik öz-yeterlikleri. Spor Bilimleri Dergisi, 25(1), 23-35. https://doi.org/10.17644/sbd.85718.

Alkan, F., Acarlı, D. S., \& Altundağ, C. (2017). Teachers' opinions towards private courses and teachers' efficacy. Çukurova Üniversitesi Eğitim Fakültesi Dergisi, 46(2), 517-540.

Aktaş, H. (2016). Akademik güdülenme ile akademik özyeterlik arasındaki ilişki: ilahiyat fakültesi öğrencileri üzerine ampirik bir araştırma. Insan ve Toplum Bilimleri Araştırmaları Dergisi, 6(3), 1376-1398.

An, B. P. (2015). The role of academic motivation and engagement on the relationship between dual enrollment and academic performance. The Journal of Higher Education, 86(1), 98-126.

Ashton, P. T., \& Webb, R. B. (1986). Making a difference: teachers' sense of efficacy and student achievement. London: Longman Publishing Group.

Bailey, T. H., \& Phillips, L. J. (2016). The influence of motivation and adaptation on students' subjective well-being, meaning in life and academic performance. Higher education research \& development, 35(2), 201-216.

Baloğlu, N., \& Karadağ, E. (2008). Öğretmen yetkinliğinin tarihsel gelişimi ve Ohio öğretmen yetkinlik ölçeği: Türk kültürüne uyarlama, dil geçerliği ve faktör yapısının incelenmesi. Kuram ve Uygulamada Eğitim Yönetimi, 56(56), 571-606.

Bandura, A. (1977). Self-efficacy: toward a unifying theory of behavioral change. Psychological Review, 84(2), 191-215.

Bandura, A. (2010). Self-efficacy. The Corsini encyclopedia of psychology, 1-3.

Balkıs, M., \& Duru, E. (2009). Prevalence of academic procrastination behavior among preservice teachers, and its relationship with demographic and individual preferences. Journal of Theory and Practice in Education, 5(1), 18-32.

Uzun Özer, Ayhan Demir \& Joseph R. Ferrari (2009) Exploring Academic Procrastination Among Turkish Students: Possible Gender Differences in Prevalence and Reasons. The Journal of Social Psychology, 149(2), 241-257.

Bozanoğlu, i. (2004). Akademik güdülenme ölçeği: Geliştirmesi, geçerliği, güvenirliği. Ankara Üniversitesi Eğitim Bilimleri Fakültesi Dergisi, 37(2), 83-98.

Bulut, R. (2014). Sosyal bilgiler öğretmen adaylarının akademik erteleme davranışlarının çeşitli değişkenler açısından incelenmesi. Unpublished master's thesis, Afyon Kocatepe Üniversitesi, Afyon. https://doi.org/10.1016/j.cell.2009.01.043

Bulut, R. \&. Ocak. G. (2017). Öğretmen Adaylarının Akademik Erteleme Davranışlarını Etkileyen Etmenler. E-Uluslararası Eğitim Araştırmaları Dergisi, 8(2), 75-90.

Calp, Ş., \& Bacanlı, H. (2016). Algılanan akademik yeterlik ve özerklik desteğinin özerk akademik motivasyon ve akademik başarıyla ilişkisi. Mehmet Akif Ersoy Üniversitesi Eğitim Fakültesi Dergisi, 1(40), 300-317.

Çakıcı, D. Ç. (2003). Lise ve üniversite öğrencilerinde genel erteleme ve akademik erteleme davranışının incelenmesi. Unpublished master's thesis, Ankara Üniversitesi, Ankara.

Çetin, Ş. (2013). Eğitim fakültesi öğrencilerinin kamu personeli seçme sınavına yönelik kaygılarının incelenmesi, Milli Eğitim Dergisi, 43(197), 158-168. 
Asuman Seda Saracaloğlu, Beste Dinçer, Muhammed Eken, Sinan Bayık - Uluslararası Eğitim Programlar ve Öğretim Çalışmaları Dergisi, 10 (1), 2020, 53-82

Çıkrıkçı, Ö., Erzen, E. (2016). Cinsiyetin akademik erteleme üzerindeki etkisi: meta-analiz gender differences on academic procrastination: Meta-Analysis,. Hacettepe Üniversitesi Eğitim Fakültesi Dergisi (H. U. Journal of Education), 31(4),750-761.

Çimen-Çoşgun, Ü., \& Sarı, M. (2015). Düşük ve yüksek mesleki öz-yetkinlik algısına sahip sınıf öğretmenlerinin dönüt verme biçimlerinin incelenmesi. Pegem Eğitim ve Öğretim Dergisi, 5(5), 533-548, http://dx.doi.org/10.14527/pegegog.2015.029.

Danışman, Ş., Koza-Çiftçi, Ş., Tosuntaş, Ş.B., \& Karadağ, E. (2016). Benlik saygısının öğretmenlerin mesleki motivasyonuna etkisi: öz-yeterlilik aracılığının yapısal eşitlik modeliyle test edilmesi, Psikoloji Çalışmaları, 36(1), 21-40.

Darling-Hammond, L. (2006). Constructing 21st-century teacher education. Journal of Teacher Education, 57(3), 300-314. https://doi.org/10.1177/0022487105285962.

Demir, M. K., \& Arı, E. (2013). Öğretmen adaylarının akademik güdülenme düzeylerinin çeşitli değişkenler açısından ıncelenmesi. Eğitimde Kuram ve Uygulama, 9(3), 265-279.

Demirtaş, H., Cömert, M., Özer, N., \& Öz, í. (2011). Öğretmen adaylarının özyeterlik inançları ve öğretmenlik mesleğine ilişkin tutumları. Eğitim ve Bilim Dergisi, 36(96), 96-111.

Doğan Altun, Z., Avcı, G., Özüpekçe, S. \& Gümüş, N. (2017). Eğitim fakültesi öğrencilerinin kamu personeli seçme sınavı (KPSS) kaygısının incelenmesi. Turkish Studies, International Periodical for the Languages, Literature and History of Turkish or Turkic, 12(33), 151-166. DOI Number: http://dx.doi.org/10.7827/TurkishStudies.12743.

Ekiz, D. (2013). Bilimsel araştırma yöntemleri. Ankara: Anı Yayıncılık.

Ekici, G. \& Kurt, H. (2012). Biyoloji öğretmen adaylarının kamu personeli seçme sınavına (kpss) yönelik kaygı ve saldırganlık düzeylerinin farklı değişkenlere göre incelenmesi. Eğitim ve Öğretim Araştırmaları Dergisi, 1(4), 294-308.

Eymur, G., \& Geban, Ö. (2011). An investigation of the relationship between motivation and academic achievement of pre-service chemistry teachers. Education and Science, 36(161), 246-255.

Gerçeker, C. S., \& Şeker, S. S. (2013). Eğitim fakültesi güzel sanatlar eğitimi bölümü resim-iş eğitimi ve müzik eğitimi anabilim dallarında okumakta olan öğretmen adaylarının akademik erteleme eğilimlerinin çeşitli değişkenler açısından incelenmesi. Journal of Turkish Studies, 8(12), 12191227. https://doi.org/10.1146/annurev.earth.31.100901.141251.

Gündoğdu, K., Çimen, N., \& Turan, S. (2008). Öğretmen Adaylarının Kamu Personeli Seçme Sınavına (KPSS) Sınavına İlişkin Görüşleri. Ahi Evran Üniversitesi Kırşehir Eğitim Fakültesi Dergisi (KEFAD), $9(2), 35-43$.

Gürşimşek, I. (2002). Öğretmen adaylarında öğrenmeye ilişkin motivasyonel inançlar ve strateji kullanımı. Muğla Üniversitesi Sosyal Bilimler Enstitüsü Dergisi, 8,135-155.

Howell, A. J., \& Watson, D. C. (2007). Procrastination: Associations with achievement goal orientation and learning strategies. Personality and Individual Differences, 43, 167-178.

ipek, C., \& Demirel, í. N. (2012). Sınıf öğretmenliği ve pedagojik formasyon programı öğretmen adaylarının öğretmenlik öz-yeterlik inançları. Bayburt Üniversitesi Eğitim Fakültesi Dergisi, 7(1), 54-67.

Karaçanta, H., \& Koç, Z. (2015). Öğretmen adaylarının KPSS kaygıSı ve bazı değişkenler açısından incelenmesi. Journal of Turkish Studies, 10(11), 869-882.

Karasar, N. (2009). Bilimsel araştırma yöntemi: kavramlar, ilkeler, teknikler. Ankara: Nobel Yayın Dağıtım. 
Asuman Seda Saracaloğlu, Beste Dinçer, Muhammed Eken, Sinan Bayık - Uluslararası Eğitim Programlar ve Öğretim Çalışmaları Dergisi, 10 (1), 2020, 53-82

Karataş, S., \& Güleş, H. (2013). Öğretmen atamalarında esas alınan merkezi sınavın (KPSS) öğretmen adaylarının görüşlerine göre değerlendirilmesi. Kuramsal Eğitimbilim Dergisi, 6(1), 102-119.

Kim, H., \& Cho, Y. (2014). Pre-service teachers' motivation, sense of teaching efficacy, and expectation of reality shock. Asia-Pacific Journal of Teacher Education, 42(1), 67-81.

Kim, K. R., \& Seo, E. H. (2015). The relationship between procrastination and academic performance: A meta-analysis. Personality and Individual Differences, 82, 26-33.

Köse, E. Ö., Diken, E. H., \& Gül, Ş. (2017). Biyoloji öğretmen adaylarındaki tükenmişlik ve kpss kaygı düzeylerinin çeşitli değişkenler açısından incelenmesi. Gazi Üniversitesi Gazi Eğitim Fakültesi Dergisi, 37(3), 991-1012.

Kutlu, N., Gökdere, M. \& Çakır, R. (2015). Öğretmen adaylarının akademik erteleme davranışı ile öğretmenlik mesleğine ilişkin tutumlarının karşılaştırmalı incelemesi. Kastamonu Eğitim Dergisi, 23(3), 1311-1330.

Malinen, O. P., \& Savolainen, H. (2016). The effect of perceived school climate and teacher efficacy in behavior management on job satisfaction and burnout: A longitudinal study. Teaching and Teacher Education, 60(1), 144-152.

Moalosi, S. W.T. (2013). Teachers' self efficacy: Is reporting non-significant results essential?. Journal of International Education Research, 9(4), 397-406.

Mişe, H. \& Hançer, A.H. (2019). Öğretmen adaylarının akademik erteleme davranışlarının incelenmesi. Folklor ve Edebiyat Dergisi, 25(97-1), 726-738.

Nathaniel, P., Sandilos, L. E., Pendergast, L., \& Mankin, A. (2016). Teacher stress, teaching-efficacy, and job satisfaction in response to test-based educational accountability policies. Learning and Individual Differences, 50, 308-317.

Nessipbayeva, O. (2012). The competencies of the modern teacher. In the $10^{\text {th }}$ Annual Meeting of the Bulgarian Comparative Education Society, Kyustendil, Bulgaria: 148-154.

Okçu, V. \& Çelik, H. Ç. (2009, May). Öğretmen adaylarının kpss'ye ilişkin görüşlerinin öğretmenlik mesleğine yönelik tutumlarına etkisi. I. Uluslararası Türkiye Eğitim Araştırmaları Kongresi, 1-3 May, Çanakkale.

Özaydınlık, K. B. (2018). Öğretmen adaylarının üstbilişsel öğrenme stratejileri ve öğretmen yeterlik algıları üzerine karşılaştırmalı bir inceleme. Hacettepe Üniversitesi Eğitim Fakültesi Dergisi, 33(1), 125-143. https://doi.org/10.16986/HUJE.2017028409.

Özenç İra, G., \& Çelebi Öncü, E. (2017). Temel eğitimde görev yapan öğretmenlerin yetkinlik algılarının incelenmesi. Turkish International Journal of Special Education and Guidance \& Counselling (TIJSEG) ISSN: 1300-7432, 6(1), 61-70.

Özer, U. \& Ferrari, J. R. (2011). Gender orientation and academic procrastination: Exploring Turkish high school students, Individual Differences Research, 9(1), 33-40.

Perera, H. N., Granziera, H., \& Mcllveen, P. (2018). Profiles of teacher personality and relations with teacher self-efficacy, work engagement, and job satisfaction. Personality and Individual Differences, 120, 171-178.

Rimm-Kaufman, S. E., \& Hamre, B. K. (2010). The role of psychological and developmental science in efforts to improve teacher quality. Teachers College Record, 112(12), 2988-3023.

Rodríguez, S., Regueiro, B., Blas, R., Valle, A., Piñeiro, I., \& Cerezo, R. (2014). Teacher self-efficacy and its relationship with students' affective and motivational variables in higher education. European journal of education and psychology, 7(2), 107-120. 
Asuman Seda Saracaloğlu, Beste Dinçer, Muhammed Eken, Sinan Bayık - Uluslararası Eğitim Programlar ve Öğretim Çalışmaları Dergisi, 10 (1), 2020, 53-82

Ryan, R. M. ve Deci, E. L. (2000). Intrinsic and extrinsic motivations: Classic definitions and new directions. Contemporary Educational Psychology, 25, 54-67.

Saracaloğlu, A. S. \& Dinçer, B (2009). A study on correlation between self-efficacy and academic motivation of prospective teachers. Procedia Social and Behavioral Sciences, 1, 320-325.

Saracaloğlu, A. S., Kumral, O., \& Kanmaz, A. (2009). Ortaöğretim sosyal alanlar tezsiz yüksek lisans öğrencilerinin öğretmenlik mesleğine yönelik yeterlikleri, kaygıları ve akademik güdülenme düzeyleri. Yüzüncü Yıl Üniversitesi Eğitim Fakültesi Dergisi, 6(2), 38-54.

Saracaloğlu, A. S., Certel, Z., Varol, R. S., \& Bahadır, Z. (2012). Beden Eğitimi Öğretmenlerinin Özyeterlik İnançları ve Denetim Odaklarının Incelenmesi. Adnan Menderes Üniversitesi Eğitim Fakültesi Eğitim Bilimleri Dergisi , 3(2) , 54-65 .

Saracaloğlu, A.,\& Yenice, N. (2013). Fen bilgisi ve sınıf öğretmenlerinin öz-yeterlik inançlarının bazı değişkenler açısından incelenmesi. Eğitimde Kuram ve Uygulama, 5(2) , 244-260.

Saracaloğlu, A.S., Dinçer,B., \& Gerçeker, C., (2018). The Relationship between Music Teacher Candidates' Academic and General Procrastination Tendencies and Test Anxiety. Journal of Education and Training Studies, 6(9), 174-183.

Schunk, D. H. (1990). Goal setting and self-efficacy during self-regulated learning. Educational Psychologist, 25(1), 71-86.

Sezgin, F., \& Duran, E. (2011). Kamu Personeli Seçme Sınavı'nın (KPSS) öğretmen adaylarının akademik ve sosyal yaşantılarına yansımaları. Türkiye Sosyal Araştırmalar Dergisi, 15(3),9-22.

Steel, P. (2007). The nature of procrastination: A meta-analytic and theoretical review of quintessential self-regulatory failure. Psychological Bulletin, 133(1), 65-94.

Şahin, H., \& Çakar, E. (2011). Eğitim fakültesi öğrencilerinin öğrenme stratejileri ve akademik güdülenme düzeylerinin akademik başarılarına etkisi. Türk Eğitim Bilimleri Dergisi, 9(3), 519-540.

Schriver, M. (1993). A Comparison of middle and junior high science teachers, levels of efficacy, and knowledge of developmentally appropriate curriculum and instruction, Journal of Science Teacher Education, 10(1), 21-42.

Terzi, M., Ünal, M. \& Çağrı Gürbüz, M. (2012). Illköğretim matematik öğretmen adaylarının matematiğe yönelik akademik güdülenme düzeylerinin bazı değişkenler açısından incelenmesi. Pegem Eğitim ve Öğretim Dergisi, 2(1),52-60.

Terzi, A. R., Uyangör, N. ve Dülker, A. P. (2017). Akademik güdülenme ve akademik erteleme ilişkisi: formasyon öğretmen adayları üzerine bir araştırma. Route Educational and Social Sciences, 4(7), 52-62.

Tschannen-Moran, M., \& Woolfolk Hoy, A. (1998). Teacher efficacy: Its meaning and measure. Review of Educational Research, 68(2), 202-248.

Tschannen-Moran, M., \& Woolfolk Hoy, A. (2001). Teacher efficacy: Capturing an elusive construct. Teaching and Teacher Education, 17, 783-805.

Tschannen-Moran, M., \& Woolfolk Hoy, A. (2002, April). The influence of resources and support on teachers' efficacy beliefs. Paper presented at annual meeting of the American Educational Research Association, New Orleans, LA.

Tuluk, G. (2014). Öğretmen adaylarının öğretmen öz-yeterlilikleri üzerine bir inceleme. Uşak Üniversitesi Eğitim Araştırmaları Dergisi, 1(1), 1-15.

Uyulgan, M. A., \& Akkuzu, N. (2014). Öğretmen adaylarının akademik içsel motivasyonlarına bir bakış. Kuram ve Uygulamada Eğitim Bilimleri, 14(1), 7-32. 
Asuman Seda Saracaloğlu, Beste Dinçer, Muhammed Eken, Sinan Bayık - Uluslararası Eğitim Programlar ve Öğretim Çalışmaları Dergisi, 10 (1), 2020, 53-82

Ümmet, D. \& Otrar, V. (2015). Kamu Personeli Seçme Sınavına (KPSS) yönelik tutum ölçeği geliştirme çalışması. Gümüşhane Üniversitesi Sosyal bilimler Dergisi, 6(13), 1-14.

Van Eerde, W. (2003). A meta-analytically derived nomological network of procrastination. Personality and Individual Differences, 35(6), 1401-1418.

Vural, L., \& Gündüz, D. (2019). Öğretmen adaylarının akademik erteleme davranışları ile bilişsel farkındalık düzeyleri arasındaki ilişki. Elementary Education Online, 18(1), 307-330.

Wu, F., \& Fan, W. (2017). Academic procrastination in linking motivation and achievement-related behaviours: A perspective of expectancy-value theory. Educational Psychology, 37(6), 695-711.

Yavuz, S. \& Akdeniz, A. (2019). Fen bilgisi öğretmen adaylarının tükenmişlik ve kpss kaygı düzeylerinin çeşitli değişkenler açısından incelenmesi, Karaelmas Eğitim Bilimleri Dergisi, 7 (2), 212-227.

Yenice, N. , Saracaloğlu, A. S., \& Özden, B. (2013). Fen Bilgisi, sosyal bilgiler ve sınıf öğretmeni adaylarının öğretmen özyeterlik algıları ile akademik kontrol odağı arasındaki ilişki. Pamukkale Üniversitesi Eğitim Fakültesi Dergisi , 34 (34), 227-250.

Yıldırım, A., \& Şimşek, H. (2013). Sosyal bilimlerde nitel araştırma yöntemleri. Seçkin Yayıncılık.

Yılmaz, M. \& Yaşar, Z. (2016). Öğretmen adaylarının Kamu Personeli Seçme Sınavına (KPSS) yönelik algıları. Bartın University Journal of Faculty of Education, 5(2), p. $644-651$. 
Asuman Seda Saracaloğlu, Beste Dinçer, Muhammed Eken, Sinan Bayık - Uluslararası Eğitim Programlar ve Öğretim Çalışmaları Dergisi, 10 (1), 2020, 53-82 